dillintritru

\section{teilriatry at}

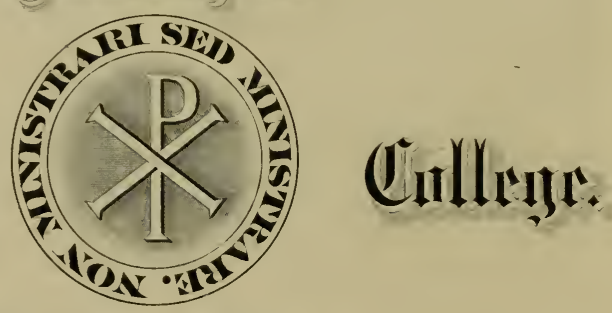

Hurdiand from

The fursturil fout.

N! 55342 






\title{
MEMOIRS
}

\author{
OF THE
}

\section{Torrey Botanical Club}

Volume VIII

I.UCien Marcus Underwood, Editor

Published by the Club

NEW YORK

1899-1902 
55342

$-10-$

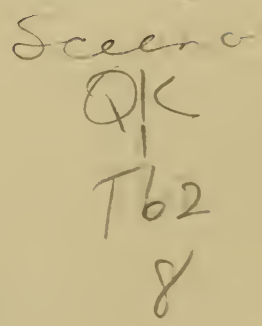

PRESS OF

THE NEW ERA PRINTING COMPANY. LANCASTER, PA. 


\section{CONTENTS}

I. Francis E. Lloyd. The comparative Embryology of the Rubiaceae. Pp. I-26. pl. I-4. Issued 26 August 1899; pp. 27-1II. pl. 5-15. Issued I 5 February 1902 .

2. Alexander W. Evans. The Lejeuneae of the United States and Canada. Pp. I I3-183. pl. 16-22. Issued I 5 February I902.

3. Elizabeth G. Britton and Alexandrina Taylor. The Life History of Vittaria lineata. Pp. I85-2II. pl. 23-3I. Issued 30 August 1902. 


\section{ERRATA}

Page I 2, I th $^{\text {the }}$ from top, for mother cell of the embryo sac, read embryo sac cell.

Page 6 I, 9th line from top, for megaspore, read megaspore mother cell.

Page 77, 2d line from bottom, for 10:252, read $30: 221$. Page 102, 6th line from bottom, for and, read in. 


The Life History of Vittaria lineata

By Elizabeth G. Britton and Alexandrina Taylor

(Plates 23-3I)

At the conclusion of our studies on Schizaea pusilla, Mr. Tracy Hazen called our attention to the fact that Francis Wolle* had figured a filamentous protonema, which he suspected to belong to a fern, but had previously described as Poterophora Donnellii. $\dagger$ It was collected on trees in Florida by John Donnell Smith who loaned us the type from which drawings have been made, as the figures given by Wolle were found to be incorrect. The urnis described by Wolle are podetia and produce spherical or cylindric gemmae which Wolle did not figure. This curious method of vegetative propagation has been figured by Goebel $\$$ in a species of Trichomanes, but as the sporophyte is still unknown in Poterophora and we knew of no epiphytal species of Trichomanes in Florida, suspicion was aroused regarding Vittaria lineata. Living plants in all stages were secured from E. W. Reasoner, of Oneco, Florida, and also from Miss Abbie M. Small at Jacksonville, Florida. We have kept these plants growing in the laboratory for more than a year, and watched the stages of their develop. ment. As far as we can learn, the gametophyte of this fern has never been described; in fact the only reference to it is in a footnote in Eaton's Ferns of North America, which states that " J. Donnell Smith and C. F. Austin found the prothalline growth of this fern very abundant on palmettos along the Caloosahatchie River, Florida." The peculiarities of its structure are remarkable, agreeing in essential particulars with those of Vittaria elongata, described by Goebel from specimens studied at the Botanical Gardens at Buitenzorg, Java.§

* F. Wolle, F. W. Algae of N. A. I20. pl. to6. I887.

$\dagger$ Bull. Torrey Club, 6: 177, 188. 1877 .

‡ Goebel, Ann. Jard. Buit $7: 78-87 . p l .10-13 . \quad 1888$.

\& Goebel, Ann. Jard. Buit. 7 : 95. pl. 12, f. 60-6I.

Memoirs Torrey Botanical Club, Volume VIII.

[No. 3 issued 30 August, 1902.] 
The systematic records of Vittaria lineata were also found to be very imperfect; specimens were much mixed in our collections and several other closely allied species had been mistaken for this species. The types of several of these need to be restudied microscopically before we can reach a correct knowledge of the limits and distribution of the American species. The material in American collections is necessarily incomplete, and the types are scattered through European herbaria. However, with what specimens and literature are available, we believe it will be helpful to give a brief survey of the history of Vittaria lineata, and to describe and figure the gametophyte of our specimens from Florida. It would be still more helpful if collectors in the West Indies would make it a point to collect the prothallia and young stages of Vittaria, and preserve them in condition for study.

The genus Vittaria is in need of revision, as there has been none made since that of Fée, ${ }^{*}$ and subsequent treatment in the Synopsis Filicum has largely disregarded the results attained in his memoir. Kunze and Fée were the first to recognize the value of the spores and sporangiasters in specific distinctions, and Fée also figured the scales and sporangia, although in many species the lip cells were omitted. The venation is obscure in many species, and in consequence has been wrongly described. Taenitis has been combined with Vittaria by some authors which tends to complicate the synonymy, and Taeniopsis was founded on the type species of Vittaria. $†$

The most recent list given of the species is that of Salomon $\ddagger$ from which the following has been compiled, but it will be found that a number of corrections have been made after consulting the original place of publication.

\section{Chronological List of the American Species}

I 753. Pteris lineata L. Sp. Pl. 1073.

I80 I. Vittaria filiformis Cav. Praelect. 270 (67 1).

1803. $V$. angustifrons Michx. Flor. bor. Am. 2: 26 I.

I 8 I 9. $V$. Schkuhrii Raddi, Fil. Bras. 5 I.

* Fée, Mem. des Foug. 3: I-24. I85I.

† J. Smith, Hook. Journ. Bot. 4: 67. 1842 .

$\ddagger$ Salomon, Nom. Gefäss. Krypt. ${ }_{1} 88_{3}$. 
I 824. V. graminifolia Kaulf. Enum. Fil. I92.

1837. V. stipitata Kze. Analect. pteridogr. 28. pl. I8. f. I.

I85 I. $V$. Gardneriana Fée, Mem. des Foug. $3:$ I 5. pl. 3.f. I.

I 85 I. $V$. flifolia Fée, Mem. des Foug. 3: 20. pl. 3. $f .6$.

I 85 I. $V$. Ruiziana Fée, Mem. des Foug. 3 : 16. pl. 3. f. 3.

I 85 I. $V$. scabrida Klotsch ; Fée, Mem. des Foug. 3: 20.

I 854. $V$. remota Fée, Mem. des Foug. $7: 26$. pl. 20.f. $I$.

1854. V. curvidentata CM. Bot. Zeitung, I2: 546. pl. I3.f. I.

1854. V. dimorpha CM. l. c. 547.pl. 13.f. 3.

I 854. $V$. pachydictyon CM. l.c. 547.pl. 13.f. 4 .

I854. V. Deppeana CM. l. c. 547.pl. 13.f. 6.

I864. V. Karsteniana Mett. Ann. Sc. Nat. V. 2 : 206.

I 864. $V$. Moritziana Mett. l. c., 207.

I 869. $V$. Orbignyana Mett. Linnaea, $36: 67$.

I 869. $V$. gracilis Moritz, Linnaea, $36: 67$.

I 877. $V$. intramarginalis Baker, Journ. Bot. I5 : 266.

I 893. V. longipes Sodiro, Crypt. Vasc. Quit. 423.

Of these $V$. filiformis, $V$. angustifrons, $V$. Schkuhrii and $V$. curvidentata have been referred to $V$. lineata as synonyms, and $V$. graminifolia has been reduced to a variety of both $V$. lineata and of $V$. curvidentata. Mettenius* expressed the opinion that $V$. graminifolia and $V$. filifolia were the same species, and figured $V$. filifolia with a cross-section of the leaf. The type of $V$.graminifolia should be found either at the University of Leipzig or in the herbarium of Count du Roemer at Dresden and the type of $V$. filifolia in the Cosson herbarium at Paris. Fée says it is remarkable for its long stipe. $V$. Gardneriana and $V$. remota are too closely allied and need more study ; $V$. Ruiziana is said to be a synonym of $V$. Moritziana by Mettenius and if so has priority over that species; $V$. scabrida has not been figured, and is apparently closely related to $V$. dimorpha in size; $V$. Deppeana has been referred to $V$. filifolia, by Mettenius, but is apparently distinct ; $V$. graciiis and $V$. intramarginalis should be compared with $V$. filifolia; and $V$. longipes should be compared with $V$. Orbignyana.

Karl Müller $\dagger$ has shown that the character of the scales surrounding the base of the leaves vary in different species, and may

* Mett. Fil. Hort. Bot. Lips. 25-27. f. $21,22.1856$.

† Bot. Zeitung, 12 : 537-548. pl. I3. 1854 . 
be either entirely parenchymatic, or the cell walls may be thickened evenly, or even papillose. This character he made use of in describing six new species, but he ignored the spores and paraphyses, so that it is hard to compare his species with those described and figured by Fée. Luerssen* followed Mettenius in reducing $V$. Deppeana to $V$. filifolia, in spite of the differences of the scales as figured by Müller, and maintained $V$. curvidentata to which he referred $V$. graminifolia as a variety.

\section{Geographical Distribution}

In the following list the type locality is given first, and then the distribution as cited by Fée, the authors of the species and subsequent lists, without any attempt to verify the determinations :

$V$. lineata, Haiti; West Indies, North and South America, East Indies (?).

V. graminifolia, Brazil ; Peru, Mexico.

$V$. stipitata, Peru; West Indies and South America.

$V$. Gardneriana, Brazil ; South America and Mexico.

$V$. filifolia, Mexico ; Central and South America, West Indies.

$V$. Ruiziana, Peru and South America. (V. Moritziana, Peru.)

$V$. scabrida, Brazil; Mexico.

$V$. remota, New Granada, South America and West Indies.

$V$. Karsteniana, United States of Colombia.

$V$. gracilis, United States of Colombia.

$V$. Orbignyana, Bolivia.

$V$. longipes, Ecuador.

$V$. intramarginalis, Jamaica.

$V$. dimorpha, Mexico.

$V$. curvidentata, Brazil.

$V$. pachydictyon, South America, Surinam.

$V$. Deppeana Mexico.

Leaving out of consideration the South American species, it will be found that ten of the above species have been reported from Mexico and the West Indies. Of these the Mexican species are most interesting and need revision. $V$. scabrida and $V$. Deppeana have not been seen in any American herbarium. In $V$. scabrida Fée † gives the length as $90 \mathrm{~cm}$.; this is probably a mis-

* Luerssen, Fil. Graeff. 92-94. 1871 .

† Fée, Mem. des Foug. 3: 20. 1852 . 
take for he says it is a small species with short fronds, and it is described in the Synopsis Filicum as two inches long, and Sodiro $\uparrow$ says the leaves are 2-6 inches. Specimens labeled $V$. dimorpha collected by F. Müller in I $848-1855$, at Orizaba, are in the Columbia University herbarium, but do not answer to the description of this species. Fournier $\$$ credits $V$. lineata, $V$. gramifolia and $V$. scabrida to Mexico, and Fée $\S$ lists $V$. filifolia from several Mexican localities and collectors.

We have not studied the Central American species, but we find among the specimens distributed by J. Donnell Smith as $V$. lineata, that no. $8 \mathrm{II}$, collected by Turckheim in Guatemala is $V$. filifolia and that no. 7489 collected by H. Pittier in Costa Rica, is probably $V$. graminifolia.

Grisebach \|| records only one species, $V$. lineata, from the West Indies, which he says occurs in Jamaica, St. Vincent and Barbadoes. Charles Wright collected in Cuba as no. 865 , in 1856 , two species, $V$. filifolia and $V$. lineata, which were distributed as one. No. 865 , of his collection of 1865 , is $V$. stipitata. Kunze 9 records $V$. graminifolia from Cuba.

$V$. Gardneriana has been collected in Puerto Rico by Blauner and Sintenis, and $V$. remota has also been credited to Puerto Rico. Fée** has reported $V$. filifolia from that Island and $V$. lineata was collected by Sintenis.

Jenman $\dagger \dagger$ has described $V$. linecrta, $V$. stipitata, $V$. remota and $V$. intramarginalis from Jamaica: the last a new species closely allied to $V$. filifolia, judging by the description and specimens received from B. D. Gilbert; it has triangular spores, but the paraphyses have not been seen. $V$. remota is described as having the venation anastomosing once besides the normal marginal one; this does not agree with Fée’s $+甘$ figures, in which the venation is oblique as in $V$. Gardneriana.

† Sodiro, Crypt. Vasc. Quit. 423. I 893.

$\ddagger$ Fournier, Miss. Scient. au Mex. et Am. Cent. I1 $4 . \quad 1872$.

¿ Fée, Mem. des Foug. 3: 15. 1852; I1, I3. 1866.

|| Grisebach, Flora of the West Indies, 674. I 864.

If Kunze, Syn. Plant. Crypt. Poepp., Linnaea, 9: 76, 77. 1833.

** Fée, Mem. II : I3. I 866 .

†† Jenman, Syn. List of Jamaica Ferns. Bull. Bot. Dept. Jam. 4: 212 . 1897.

廿甘 Fée, Mem. 7 : 26. pl. 3o. f. 1 . 
Haiti is the type locality for $V$. lineata, but we have never seen a specimen of Vittaria, from Haiti or Santo Domingo. Specimens were distributed from Berlin, determined by Kuhn as $V$. graminifolia var. filifolia collected by Hahn on Martinique. $V$. filifolia has been credited by Fée to Guadeloupe collected by L'Herminier, and $V$. lineata was collected on Trinidad by Fendler. A dwarf form of $V$. lineata also occurs in the Bahamas. $\mathrm{Mr}$. Britton has collected sterile specimens of $V$. filifolia on St. Kitts.

\section{History of the Gametophyte}

The statement has been made that the gametophyte of Vittaria lineata has not been described, and so far as we knew, the gametophyte was unknown in all the other American species. Professor Underwood has called our attention to a copy of Lindenberg's monograph of the Ricciaccae * which formerly belonged to Austin, in which Austin had written opposite the description of Riccia reticulata, "a species of Vittaria." Lindenberg had classed it among the "Species dubiae." Riccia reticulata was described by Swartz $\dagger$ as having the fronds laciniate, glabrous and reticulate. He referred to it specimens from the Island of [New ?] Providence described by Dillenius $\$$ as Lichenoides gelatinosus tenue reticulatum. Swartz $\S$ stated that it grew on trees covered with mosses in the mountains of Jamaica, and described it as follows :

Riccia ? RETiculatA. "Frons membranacea, plana, difformis, lobata, laciniata, latitudine unciales, laciniis linearibus, saepe bipartitis, pollicaribus, glabra, obscure viridis, tenuissime reticulato-venosa. Obs. Ob texturam teneriorem Hepaticis conjungere malui quam Lichenibus." The illustration given by Dillenius is simply an outline, but the figure and description given by Lindenberg agree exactly with no. 327 from St. Kitts, collected by Mr. Britton in I90I, which he also took for a hepatic. It proves to be the gametophyte of a species of Vittaria, probably $V$. filifolia, the leaves of which were collected in another ravine but were not

* J. B. W. Lindenberg, Mon. Ricc. 501. pl. 36. f. 1-4. 1836.

† Swartz, Prod. Ind. Occ. I46. 1788.

‡Dillenius, Hist. Musc. 1: 138. pl. 19. f. $21 . \quad 1741$.

\& Sw. Fl. Ind. Occ. $3:$ 1883. 1806. 
found with or near no. 327. This implies an independent existence for the gametophyte, which agrees with that of $V$. lineata in being proliferous by its septate gemmae and in being lobed, but it differs in the shape and size of the thallus, the shape of the lobes, and the cellular structure. However, the specimens were dried when examined, as were Lindenberg's, whose description and figures were drawn from the type of Riccia reticulata, belonging to Swartz, which had been collected thirty years at the time the drawings were made. The cell contents had shrunk, forming a fine mesh of the strings of protoplasm, radiating from the nucleus of each cell, which gave the dotted and reticulated appearance described by Swartz as visible with a hand lens. The gemmae also must have disappeared, for they are neither figured nor described. In the specimen from St. Kitts, they are most abundant on the truncate ends of the long, narrow lobes.

That the gametophyte of Vittaria maintains an indefinite and independent existence, without forming the sporophyte, seems to be an established fact. It is autoicous, the archegonia being borne mostly on the thallus, and the antheridia on the gemmae. In a climate where violent winds and heavy rains are frequent the gemmae would be liable to be detached without fertilization having taken place. Dr. Campbell reports having seen in Jamaica, enormous sterile prothallia, forming circular mats at least three inches in diameter on the trunks of palms, and resembling a liverwort. Dr. Campbell * has also described and figured a prothallium collected in the Sandwich Islands, similar to that of Vittaria, which he has referred to a species of Hymenophyllum. $\mathrm{He}$ states that they lived for two or three years in his laboratory. He also states that "Goebel has described in Vittaria a type of prothallium recalling that of Hymenophyllum, both in its large size and extensive branching." From our present knowledge we are inclined to believe that Campbell has mistaken the genus, and that these prothallia should be referred to Vittaria, probably to $V$. elongata.

* Campbell, Mosses and Ferns, 362. f. 187, 188. 1895. 


\section{Symopsis of the North American species of Vittaria*}

Stipes green; I-2 cm. long, margins recurved when dry.

Spores reniform, paraphyses enteriform; scales papillose, serrate.

Leaves $30-120 \mathrm{~cm}$. long, 2-3 mm. wide, pendent.

Leaves IO-1 $5 \mathrm{~cm}$., narrowly linear, erect.

Spores tetrahedral; scales smooth.
$V$. lineata.

V. graminifolia.

V. intramarginalis.

Stipes green or yellow, 10-15 cm. long ; margins revolute.

Spores tetrahedral, paraphyses mastoid.claviform, scales smooth, entire.

V. filifolia.

Spores tetrahedral ?; paraphyses enteriform?; scales papillose, aristate, serrate.

Stipes green, short; leaves 4-16 cm. long.

V. Deppeana.

Spores tetrahedral; paraphyses cucullate; scales dentate. $V$. scabrida.

Spores ?; paraphyses ?; scales aristate, papillose, entire.

$V$. dimorpha.

Stipes brown or black, 2-9 cm. long; margins flat; spores reniform.

Leaves $20-30 \mathrm{~cm}$. long; paraphyses cyathiform.

Leaves 7-9 mm. wide; rhizome creeping. $\quad V$. Gardneriana.

Leaves 6-12 mm. wide; rhizome erect. $\quad V$. remota.

Leaves I meter long, 3-5 mm. wide; paraphyses pyriform. $V$. stipitata.

\section{Vittaria lineata (L.) J. E. Smith.}

Lingua cervina longissimus \& angustissimis foliis. Plumier Fil. Am. I 23. pl. 143. I 705.

Phyllitis lineata, graminis folio longissimo. Pet. Fil. I 26. pl. I4. I 7 I 2.

Pteris lineata L. Sp. Pl. I 073. I 753.

Vittaria lineata J. E. Smith, Mem. Acad. Roy. Sci. Turin. 5 : 4I 3. I 793.

$V$. lineata Swartz, Schrad. Journ. 2: 72. I800; Syn. Fil. I 09. I 806.

$V$. filiformis Cav. Praelect. Bot. 270, 67 I. I80 I W Willd. Sp. P1. 5: 405. I $80 \mathrm{I}$.

V. angustifrons Michx. Flor. Bor. Am. 2: 26I. I803; non Bory. Itin. 2: 325. I 804.

$V$. Schkuhrii Raddi, Fil. Bras. 51. I 819.

Taeniopsis lineata J. Smith, Hook. Journ. Bot. 4: 67. I842. $V$. lineata Sw. Fée, Mem. Fam. Foug. 3: I7. 185 I ; Hook. Sp. Fil. 5 : I 80. I 864 ; Hook. \& Baker, Syn. Fil. 396. I874; in part ; Eaton, Ferns of N. Am. I : 289. I879; Sodiro, Crypt. Vasc.

* This synopsis is necessarily incomplete, owing to deficiencies in the descriptions, and lack of knowledge of the types. 
Quit. 420. I 893 ; Jenman, Bull. Bot. Dept. Jamaica, 4: 25 I. I 897.

$V$. curvidentata CM.? Bot. Zeitung, I2: 546 . I 854 .

Linnaeus founded this species on the plate and description given by Plumier, cited Santo Domingo for the type locality, and adopted the specific name from Petiver's description, according to citations. Plumier figured the species very clearly on a large quarto plate, and described it in French and Latin; as this work is rare in America, it seems desirable to quote his description.

\section{Planche CXLiII.}

"Langue de Cerf à feuilles tres longues et tres étroites. La racine de cette Langue de Cerf n'est proprement qu'un amas de plusieurs pédicules pourris mélez de plusieurs petites fibres roussatres, \& toutes couvertes de mousses: elle jette quantité de feuilles tres longues \& tres étroites, car elles n'ont pas plus d'une ligne \& demie de large, sur environ trois pieds de longueur: elles sont fort pointuës, solides, épaisses comme du parchemin, unies, \& d'un vert assez gay par devant, mais toutes traversées de biais en derriére par quantité de petites nervûres tres proches les unes des autres : outre ce elles ont aussi le bord replié en dedans, \& couvrent tout le long de leur pli un nombre infini de tres petites vessies noiratres.

J'ay rencontré cette Plante en plusieurs endroits des Isles de l'Amérique, particuliérement à la Source de la Riviére Froide, vers le quartier du Port de Paix, dans l'Isle Saint Domingue."

Plumier's description agrees very well with the general acceptance of the characters of the species. It must be taken as the type of the genus, for J. E. Smith founded the genus on Vittaria lineata; there is no reason for taking up Tacniopsis of $\mathrm{J}$. Smith, nor for citing Swartz as the authority for the species. It has been found that the sporophyte only has been described, and in the case of some of the synonyms, in the briefest and most superficial manner, giving only macroscopic characters. It follows that further study may reinstate some of these as species. This may be true of $V$. filiformis Cav. "foliis filiformibus, tripedalibus, glaucis." Fructification as in $V$. lineata ; habitat Peru, or of $V$. angustifrons Michx. "frondibus simplicibus, integerrimis angus- 
tissime longissimeque linearibus, debilibus. Fructification linea continua sub replicato frondis margine, ab istius sinu distincta. Hab. in Florida juxta ammen Aisa-hatcha."

It is not likely that the Florida species will be found to be distinct from the West Indian, but until the gametophyte of both is known there is still this possibility. Fée has suggested it in his memoir, as he states that he has seen in Willdenow's herbarium a specimen of $V$. lineata collected in Jámaica by Swartz, which had bright amber-colored sporangiasters, with the terminal cell mastoid or elongated pyriform, and that he also had a specimen collected in Florida from Richard which has ribbon-like sporangiasters. $\mathrm{He}$ believed the two plants were distinct species. Yet he contradicts himself in his description of $V$. lineata which he attributes to Swartz and states that the sporangiasters are vittate, with dilated colored contorted apex. He also states, that although $V$. lineata is the oldest species, there exists the greatest vagueness and uncertainty in the descriptions and that he considers it to be exclusively American. Unfortunately, he did not figure $V$. lineata, only the variety graminifolia Kaulf, without stating whether he had seen the types. He also took up Taeniopsis, as a subgenus, and referred $V$. lineata to it ; we have shown that this position is untenabie. In this he was followed by the authors of the Synopsis Filicum, who also reduced $V$. filifolia and several Asiatic species to $V$. lineata. We have already shown in the key, that $V$. filifolia has the characters of a good species, but we have not studied the exotic species.

There is another character of $V$. lineata which has been overlooked, probably because only mature, fruiting specimens are generally collected. This is the first leaf stages of the plant, which are quite distinct in size and shape, as may be seen by the plate. Jenman has described similar leaves in $V$. intramarginalis, of which he says: "A small plant which much resembles seedlings of $V$. lineata from which it is readily distinguished by the distinct small barren fronds (not however present in full-grown plants)." *

As none of the descriptions have been found to be complete, we have framed one from fresh material, and have necessarily been obliged to limit it to Florida specimens.

* Bull. Bot. Dept. Jam. 4: 213. I897. 
Gametophyte capable of indefinite growth and duration, branching irregularly or bifurcating into numerous lobes, which are proliferous by gemmae borne from podetia, usually on marginal cells ; serving to propagate the plant asexually, and also rendering it autoicous by bearing antheridia ; archegonia borne on the under side of the thallus.

Sporophyte forming rudimentary leaves, $\mathrm{I}-4 \mathrm{~cm}$. long, spathulate, with a single central vein ending below the apex or forming a loop in the rounded apex ; rhizome short, divided, creeping, sparingly, densely covered with lanceolate, serrate, filiform-pointed scales, with papillose walled cells; leaves dark green or glaucous, two-ranked, crowded in dense compact pendent tufts, often $2-3 \mathrm{ft}$. long, $2-3 \mathrm{~mm}$. wide, coriaceous, three-veined, the midvein pinnate and anastomosing with the lateral veins, with a deep sporangial groove over each lateral vein, in which the stomata are borne, paraphyses branching twice, usually forking, cylindric, the end cells curved and larger, brown; spores reniform, smooth, .027 $\times .054$ $\mathrm{mm}$.

Florida, as far north as St. Augustine; also credited to South Carolina by Fée and Hooker, but probably by mistake. Presumably the same as the West Indian species, of which the gametophyte is still undescribed, and the microscopic structure imperfectly known.

\section{Gametophyte*}

Prothallium.- $\left(F \cdot I_{-3} 8\right)$. The gametophyte of Vittaria lineata is an irregularly branched prothallium $(f . I-4)$, consisting of a single layer of distended cells containing chlorophyl ( $f$. I4, I5). New prothallia may arise from any one of the marginal cells, or from two or more of the lamellar cells of the prothallium $(f$. 5-8). This capacity for vegetative reproduction by proliferation of the prothallus must be of great service to this species which is epiphytic on trees and much subject to the attack of small animals. Almost any fragment of the prothallus might continue growth independently.

The younger portions of the prothallia assume a horizontal position at right angles to the trunk of the tree to which they are attached, extending to a distance of $9 \mathrm{~mm}$. in some instances. As the formation and growth of rhizoids proceeds successively in

* The material on which the anatomical study is based was collected by Miss Abbie M. Small at St. Augustine, Florida, 22 Feb. 190r, on the bark of the palmetto. 
these younger regions, however, the rhizoids penetrate the bark of the tree and then draw the prothallus down against it. The rhizoids may be formed in clusters $(f . I)$ from an undifferentiated cell of the prothallus, or from a proliferation consisting of a single cell. Rarely more than one rhizoid originates from a single cell. The rhizoids are long colorless structures rarely branching near the apex, and sometimes distended at the base ( $\left.f . I_{3}\right)$.

The prothallium is occasionally monoicous-autoicous, but more frequently pseudo-dioicous with the antheridia and archegonia produced indirectly from the same plant. In such instances the archegonia are borne on the main prothallium, which also produces gemmae from which antheridia originate.

Barrel-form or spherical sterigmata containing chlorophyl arise from the margin, apex and occasionally from the middle of the prothallus bearing gemmae in great numbers. A sterigma may give rise to one or several gemmae, and these gemmae may divide repeatedly before falling off. The gemmae may either lie on the surface of the prothallus or stand out from it after the manner described by Goebel, who found the first position assumed in Vittaria elongata and the second in Monogramma paradoxa $(f .19-25){ }^{*}$ A sterigma may give rise to several sterigmata before the gemmae are produced $(f .22)$. The gemmae are very similar to those of Vittaria elongata as described by Goebel and are in the form of spindles composed of 5 to I I moniliform cells ( $f$. $28,29)$. The terminal cells may give rise to rhizoids, but these and the antheridia may be produced from any one of the cells of the spindle $(f \cdot 30-33)$. The gemmae produce prothallia in various ways, and also may develop other gemmae, and antheridia $(f .33-37)$.

Antheridia. - The antheridia are produced either directly from one or more cells of the gemmae $(f .39,40)$, or on the lower surface of the prothallium, the margin and occasionally on the upper surface. A prothallium sometimes bears both antheridia and archegonia $(f .56)$. The development of the antheridia is as follows: A cell in any one of the positions named sends out a protuberance containing chlorophyl which becomes club-shaped

* Goebel, K. Morphologische and Biologische Studien. Ann. Jard. Bot. Buienzorg, 7 : 78-107. 1888 . 
and then cuts off the terminal portion by a partition wall, making two cells of unequal size, the lower being much larger ( $f$. $40 b, 4 I)$. The apical cell becomes almost spherical, and the next wall formed in it is funnel-shaped, connecting with the wall previously formed in such manner as to separate a central cell. A third wall is now formed in the apical portion of the peripheral cell cutting off a cap cell shaped like a watch glass ( $f$. 43-45). The antheridium now consists of four cells, a pedestal cell, a hemispherical central cell enclosed by a cylindrical peripheral cell, and crowned by a cap cell $\left(f .4^{2}\right)$. Further division occurs in the peripheral cell in rare instances. The first division wall in the central cell is generally longitudinal, and the second one is at right angles to it, and this sequence is followed during the formation of an indefinite number of mother cells $(f .42,44)$.

An antherozoid is produced in each mother cell. The connecting walls of the mother cells dissolve and the antheridia lie free in the antheridium $(f .48 a)$. When the antheridium is ripe the antherozoids are ejected by the swelling of the peripheral cell and of the upper contiguous portion of the pedicel $(f .49)$ which is pushed up into the antheridial cavity; the cap cell is ruptured either at the center or at one side. When the antherozoids escape from the antheridium they are enclosed by a thin membrane, which is thrown off shortly after their liberation. The antherozoids uncoil with a whip-like motion, curling and uncurling very rapidly during a few seconds, the movements of the cilia increasing in rapidity. The action of the cilia propels the antherozoid at a comparatively great speed, and they remain active for some time (f. 5o).

Four antheridia were seen in the act of discharging the antherozoids: the latter escaped in rapid succession, although two or three came out together in some instances. It was not difficult to count the emerging antherozoids, and two antheridia were found to contain twelve and another twenty-four. One antheridium was emptied in a little more than a minute, and the antherozoids burst the enclosing membrane in forty seconds or less after emergence. The entire number (twelve) had freed themselves in this manner in less than two minutes from the time action began. A portion of the mother cell in the form of a hyaline sphere with a granulated 
center was carried by the antherozoids to which it was still attached forty-five minutes later.

Archegonia $(f .57-60)$. - The few archegonia that were seen occupied positions similar to those of Vittaria elongata as described by Goebel, being borne on the under surface of the prothallium, and also on the small lobes among the rhizoids. The archegonia have a slightly curved neck, although the number of cells shown on the concave and convex surfaces are the same, being four or five in number.

\section{The Sporophyte}

The sporophyte generally remains attached to the gametophyte for some time after its formation $(f .89-g I)$.

RHIzome. - The main axis of the sporophyte consists of a dorsiventral rhizome with short internodes bearing the tufted leaves in two ranks, the roots are very numerous and completely clothe the lower surface of the rhizome. The growing portion of the rhizome appears as a fleshy green bulbous formation with a conical apex, completely enveloped in long brownish scales $\left(f .5^{8}\right.$, 59). Glands, similar to those of the leaves and hairs, resembling those of the root are also present. The apical cell is wedgeshaped and the differentiation of the tissues follows quite closely the advance of the apical meristem $(f .61,62)$.

In the earlier stages of development of the stelar tissues they appear as a cylinder of thin-walled elements $\left(f .6_{3}\right)$ in which the scattered groups of protoxylem soon appear $(f .64 d)$. The metaxylem next appears as a complete cylinder of scalariform tracheids $(f .65)$. The metaphloëm is much more highly developed externally to the cylinder and consists of numbers of sieve cells separated from the metaphloëm and from the pericycle by parenchymatous elements. The pericycle is well defined $\left(f .6_{5} a\right)$. As the cylinder is traced upward along the stem, gaps appear where an entire segment of the fibrovascular ring is sent out into a leaf $(f .66)$. The external cortex, which is composed of extremely thin-walled elements in the younger specimens, becomes somewhat thickened and perforated in older organs. The epidermis does not participate in the thickening however.

RooTs. - Roots are produced in great numbers from the rhizomes opposite the leaves and are usually quite advanced in devel- 
opment as soon as visible. Hairs are produced profusely, originating $.5 \mathrm{~mm}$. from the tip. The roots quickly penetrate the bark of the palmetto tree to which the plant is attached, and as they are exposed to the light in various places form chlorophyl.

The root hairs measure from $0.6-4.5 \mathrm{~mm}$. in length and .O I 5 .0299 in width. The hairs seldom form cross walls but occasionally branch near the apex, although the branches do not attain any considerable length. The roots branch profusely: one $\mathrm{I} 3 \mathrm{~mm}$. long produced 6 branches and I branch $7 \mathrm{~mm}$. long produced 3 branches $(f .88)$. The central cylinder of the root is apparently diarchic $(f .86,87)$ and the endodermis is plainly differentiated. The cortex consists of 4-6 layers of large cells with strongly differentiated walls; the outer rows show this striation less plainly however. The outer layer immediately internal to the epidermis contains large numbers of crystalline bodies connected with their inner walls $(f$. 87, 88). The epidermal cells are large, the thin outer walls being pressed inwardly in many. instances.

Sterile Leaves. - The leaves of Vittaria lineata show progressive variation in form and venation $(f .80-95)$. Those which arise earliest are spatulate and have a single central vein, later they show a branching venation $(f .89,93)$. The laminar portion of the first leaves is flattened and the cross section does not show such complete dorsiventral differentiation as may be found in the leaves arising later. They are but slightly curved when they emerge from the scales, and the curvature soon disappears. The epidermal cells are somewhat longer than broad with wavy walls $(f$. 97). Among these cells are a few elements with pointed ends and wavy walls $(f$. $98 a)$, which are most abundant near the fibrovascular bundles. The epidermal cells generally contain chlorophyl with the exception of the hyaline border. The latter is composed of elongated elements with oblique end walls $(f .96 a)$. The epidermal cells of the petioles are prosenchymatous and rarely have wavy walls. Stomata occur on the under side of the lamina but do not occur immediately external to the veins. Numbers of club-shaped bodies, composed of three cells $(f .97 a)$, resembling glands, are to be found on both surfaces. Scales arise on the basal portion of the earlier leaves di- 
rectly external to the bundles, while these formations occur more abundantly on leaves developing later yet they are rarely over a bundle $(f \cdot g 9)$.

Leaves formed from the rhizome at a later stage of growth show a variation in form from oblanceolate to linear $(f .94,95)$. Such leaves have a vein extending through the middle and one along each margin with numerous anastomosing branches. Glands and scales are somewhat more numerous and the epidermis contains but little chlorophyl.

The latest leaves formed show the greatest length and are ridged over the nerves on the upper surface, bearing scales between the central and marginal veins ( $f$. IOQ). These scales, while no more numerous on the upper surface than on the lower, are frequently larger, measuring as much as $1.9 \mathrm{~mm}$. in length. It is found that the regularity of arrangement of the stomata and the increase of the ridges of the leaves increases as a form approximate to that of the adult is reached ( $f$. IO4).

Sporophylls. - The sporophylls are long linear coriaceous leaves with a short petiole exhibiting the epinastic growth of so many ferns. The numerous scales which doubtless serve as a protection to the unrolling leaves persist in mature forms ( $f$. IOQ$I I I)$. The dorsal surface is marked by two deep grooves immediately external to the lateral veins, and these grooves contain the stomata, glands, sporangia and accompanying paraphyses ( $f$. IO4IO9). The two fascicles of stelar elements given off from the edges of the incomplete cylinder in the foliar gap in the rhizome do not fuse until some distance in the petiole has been traversed, and the lateral branches are given off before the fusion is complete $(f . I 02, I 03, I, 6,7)$. The lateral veins and the central vein are connected by various anastomosing branches $(f .102-106)$. The central vein runs quite to the apex of the leaf $(f .94-95)$, while the lateral veins end free a short distance below the tip or terminate in an anastomosing branch $(f .103-109)$. The vascular elements of the leaves are the same as the rhizome in composition, and the bundles are enclosed in a sheath of two to six layers of cells with perforated walls $(f .108 d, f)$. The mesophyll of the upper side of the leaf is closely packed and contains a large amount of chlorophyl, giving this surface a dark green color $(f$. II $)$. The 
mesophyll of the lower side is more loosely arranged and contains less chlorophyll $(f$. II 6$)$.

The epidermis is composed of elements with very thick walls except in the grooves ( $f$. II4-II9). A reduction in size is noticeable pver the middle and lateral veins and at the margins of the leaves. Chlorophyl is to be found in the epidermal cells in the grooves but seldom elsewhere. The epidermis of the grooves is uniformly thin-walled and gives rise to stomata and glands; the latter are also found over the entire surface of the sporophyll. A narrow band of two to six rows of cells immediately external to the bundle underlying the groove bears the sporangia and paraphyses $(f .12 j e)$. One to four layers of prosenchymatous cells are to be seen underneath the epidermis of the upper side of the leaf $(f . I I 4 b)$. Similar elements are to be found on the lower side of the leaf between the grooves, and these cells are somewhat larger than those of the upper surface $\left(f .{ }_{1} 16 b\right)$. These hypodermal prosenchymatous elements are generally free from chlorophyl and are separated by numerous large air-spaces, giving the region a light gray color. The absence of these ele. ments in some instances cannot be accounted for.

Scales. - Scales are most abundant on rhizomes and least so on the leaves produced earliest $(f \cdot 72-74)$. The first leaf formed may bear but one scale while the later leaves may be covered with them. The scales are never more than one cell in thickness and nine or ten in width, attaining a length of $5 \mathrm{~mm}$. and a breadth of .4-1.I mm. The growth of these structures is longcontinued and the basal cells may be in a state of division while the apical portion may be withered and brown $(f \cdot 75-82)$. The thin walls of the younger cells at the base measure I.9 $\mu$ in thickness which later increases to as much as $19.2 \mu$, which is a most noticeable multiplication. This thickening is confined to the cross walls, the outer walls not participating in this increase ( $f .76 a, 8 I, 82 a)$. The thickened walls show great numbers of dots or minute papillae, which are most numerous in scales borne on the stems and are not easily found in scales of the earlier leaves. Both the thickening of the walls and the formation of papillae are less marked in the marginal region of the scales.

Stomata. - Stomata are present only in the grooves of the 
leaves. In the formation of these organs the upper portion of an epidermal cell is cut off by a wall having a horse-shoe shape in surface view $\left(f .124^{b}\right)$. The newly formed cell appears to contain chlorophyl and the nucleus increases in size while the protoplasm becomes granular ( $f$. I25c). This mother cell divides along a line parallel to the long axis of the epidermal cell from which it arose $(f .126 e)$. The later stages of the splitting of the wall and the development of the guard cells follows in the usual manner $(f .127)$. The original epidermal cell from which the stomatal mother cell was cut off undergoes some alterations and it is difficult to distinguish it from its neighbors $(f . I 2 I, I 22)$.

GLANDS. - The glands are club-shaped, measuring about .08 $\mathrm{mm}$. in length and consist of three cells. These organs originate from the upper or apical end of the epidermal cells on both surfaces of the leaves and are inclined toward the apex of the leaf. The cross walls become suberized in a few cases and turn a rich golden brown $(f .97,110,112,128)$.

Sporangia. - The sporangia and the attendant paraphyses are borne on the epidermal cells in the bottom of the two grooves on the under sides of the sporophyll ( $f .123, I 29)$. The margin of the leaf and the walls of the groove fold over and cover the sporangia and form a false indusium. An examination of any single sporophyll will show the presence of sporangia in all stages of development and these bodies are produced in such great profusion that many are not brought to full development. The principal features in the development of the sporangia are as follows: An epidermal cell sends out a tubular extension in which a wall soon appears parallel with the outer wall of the epidermis $(f .130,131,136)$ and a second wall cuts oft a portion of the tube which becomes the sporangial stalk. Occasionally two or more transverse walls are formed in the basal portion of the structure before the terminal portion constituting the sporangial mother cell begins to divide $(f .130)$. Longitudinal divisions in the basal portion take place later. The sporangial mother cell first divides obliquely $(f .130,133 b)$ and then a second wall is formed at right angles to this $(f .130,134 c)$. A third and fourth division takes place resulting in the final formation of four outer cells which will constitute the wall of the sporangium 
and a fifth central tetrahedral spore mother cell $(f .130,136 d)$. The cells which are to form the annulus divide by parallel walls into I $3-15$ cells $(f . I 3 I)$ which extend from the stalk at the base of the sporangium over the back a short distance down the other side, where they join with the thin-walled cells which connect with the lip cells $(f .133 b)$. When the sporangium is young, these cells have thin walls and become inflated and raised above the other cells $\left(f .1_{33} a\right)$. These cells contain chlorophyl which is often retained until the spores are fully formed.

As the sporangium ripens, the walls of the annulus thicken considerably with the exception of the dorsal wall, becoming cuticularized $(f .134 a)$ and take on a golden brown color which later turns to a dull brown. The dorsal walls turn a dull yellow, and frequently bend back toward the inner walls of the cells, so that the cross walls form ridges along the annulus of the old sporangium. The other cells of the sporangium also divide. The frontal cells are generally eight in number and extend from the annulus to the pedicel at the base of the sporangium. They are composed of two kinds of cells, those whose walls do not thicken to any extent-called connective cells-and those whose walls thicken considerably forming the lips. There are four lip cells and they occupy the center of the row of seven or eight, occasionally nine $(f .133 c, 134 c)$. These lip cells differ greatly from the other cells of the sporangium, having a short longitudinal diameter and a very long radial one. They are connected with the annulus by one to three thinner walled cells, and with the pedicel by two $(f .133 b b, 134 b b)$. The two lip cells, which occupy the center of the group of four, frequently thicken their walls to a greater extent than the other two, and it is between these two cells that the sporangium opens when the spores are ripe ( $f .134)$, the slit extending back generally in a straight line through the thin walls of the other cells almost to the annulus. The central tetrahedral cell of the sporangium divides by oblique walls until another tetrahedral cell has been formed inside of it ( $f$. I 30 o $f)$, this inner cell dividing up into the spore mother cells and the cells between this cell and those constituting the sporangial wall form the tapetal cells ( $f . I_{3} O$, $9 g)$, which dissolve after a time so that the spore mother cells 
lie free in the sporangium. Each mother cell divides into four spores. These ripe spores are reniform with a smooth surface.

PEDICEL. - The pedicel is long and consists of three or more cells, though only one cell wide until near the sporangium, where the first longitudinal walls are formed $(f .139,9,133 e, 134 e$, $I 35, I, 2)$; here it is generally two cells in width, less often three, though at the base of the sporangium there are almost always three cells. These small cells are formed at or near the front of the sporangium $(f .133,134)$. As the sporangium ripens all the cells of the upper part of the pedicel become inflated and throw the sporangium back ( $\left.f . I_{34}\right)$, so that when the split occurs, and the lip cells open by the everting of the annulus, the spores have a less interrupted access to the opening of the groove, their original position being such that did they keep it during the discharge of the spores many of them would become entangled among the branches of paraphyses from which they would be powerless to escape.

PARAPhyses. - The paraphyses develop before and with the sporangia and frequently attain a large size while the sporangia are still very immature. They are always multicellular and branched, except when young ( $f$. I29); they grow to some length as a single cell before they branch into two or three divisions ( $f .129,136-$ 139), the first cell of each forming a stalk. The round branches generally branch in their turn. The cells are two or three times longer than wide, each containing a good-sized nucleus and some chlorophyl; as they grow older they become discolored and shrivel up. The branches terminate in cells which are always very long, much wider at their apex and generally curved $\left(f .{ }_{3} 6\right.$, 137).

\section{SUMmaRY}

The gametophyte of Vittaria lineata is an irregularly branched, pseudo-dioicous prothallium, bearing the archegonia and giving rise to gemmae which bear the antheridia and also produce new prothallia.

The antheridia are produced in great numbers, rarely on the same prothallium with the archegonia. From twelve to twentyfour antherozoids are produced in one antheridium and the opening occurs in the center of the cap cell, or at its junction with the 
peripheral cells. It ruptures by the swelling of the peripheral cell or cells, and the portion of the pedicel immediately under the antheridium; this drives the wall that separates them up into the antheridial cavity, and ejects the antherozoids.

The archegonia occur among the rhizoids near the margin, on the under side of the older portions of the prothallium; also on specialized branches which are formed at the margin of the main prothallium. They have slightly curved necks, but the rows of cells in both the anterior and posterior sides are equal in number.

The rhizoids are unicellular, simple or branched, structures and are produced either directly from a cell of the prothallium or by the formation of an initial cell.

The sporophyte consists of a creeping, dorsiventral rhizome, bearing its leaves ordinarily in two ranks. It frequently branches and the internodes of both stem and branch are so short that the leaves appear crowded together. The growing point appears as a fleshy green bulb which is densely covered by brown scales. having a structure peculiar to this genus. The rhizome has a wedge-shaped apical cell and a concentric, tubular bundle, with foliar-gaps associated with the leaf-bundles.

The roots are produced near the growing tip and are usually twice as numerous as the leaves. They have a normal root-cap and an axial diarch bundle, the two groups of xylem are generally united after a time by large tracheids. The walls of the parenchymatous cells are strongly striated and in the young roots there are crystalline substances formed against the inner walls of the cells immediately under the epidermis. The roots branch frequently and the branching appears to bear a definite relation to the original xylem groups of the diarch bundle.

There are three kinds of leaves; first, the rudimentary ones which are spathulate and long-petioled, usually with a single central vein; second, the young sterile leaves, which are shortpetioled, oblanceolate to linear, and show all gradations of venation, from the simple central vein to the three veins which characterize the sporophyll. The sporophylls are short-petioled and linear.

The venation of the leaf arises from two primary bundles, each giving rise to one smaller one which become the lateral bundles 
of the leaf. The larger portion of the two primary bundles unite to form the central bundle; these three bundles run parallel with the long axis of the leaf and are united with each other at intervals by small strands taking an oblique apical course from the central one to each lateral one.

The sporophyll has two deep dorsal grooves, running parallel with the lateral bundles and just over them ; in these grooves occur the stomata and glands, and in them are borne the sporangia and paraphyses. All the leaves bear scales which show a higher order of development as the leaves approach the type of the sporophyll.

The sporangia are long-stalked and spherical with an annulus of about fourteen cells, four lip cells and four connectives. The spores are reniform with a smooth outer coat. The smaller cells on the pedicel at the base of the sporangium become very much inflated and when the sporangium opens they tilt it back, thus aiding in the escape of the spores. The paraphyses are longstalked, branched and multicellular; the terminal cells being longer, curved, and enlarged at the apex.

\section{Explanation of Plates}

The figures were drawn with a magnification twice that indicated and the resulting figures were reduced one half.

\section{Plate 23}

FIG. I. Under side of a prothallium, showing its irregular branching : $a$, rhizoids ; $h$, sterigmata. $\times 7$.

FIG. 2. A young prothallium showing sterigmata along margin. $\times 7$.

FIG. 3. Prothallium showing manner of branching at apex. $\times 6$.

FIG. 4. An older piece with the archegonia just forming. $a$, rhizoids; $b$, archegonia ; $c$, sterigmata; $d$, young sporophyte. $\times 9$.

FIG. 5. Margin of prothallium at apex, showing branching and $b$, sterigmata. $\times 25$.

Figs. 6, 7. Young prothallia starting from margin of old ones. $\quad X \mathbf{I} 20$.

FIG. 8. A young prothallium, $a$, with three growing points starting from a single cell of an old prothallium. $\times 25$.

FIG. 9. Four marginal cells of the prothallium, each one giving rise to a rhizoid. $\times 87$.

FIG. Io. Same as Fig. $9 . \times 87$.

FIG, II. A rhizoid formed from an initial cell. $\times 87$.

FIG. 12. A rhizoid formed from two cells. $X \mathbf{I} 20$.

FIG. I3. Rhizoid with inflated cell. $\times 87$. 
FIG. I4. Side view of portion of prothallium showing inflated cells ; $a$, rhizoids ; $b$, sterigmata with gemmae and also curved apex. $\times 25$.

FIG. I5. Portion of prothallium with apex recurved; gemmae are shown at the margin. $\times 25$.

FIG. I6. Apex of prothallium, $a$; $b$, sterigma and gemmae ; $d$, filament growing from the margin ; $e$, sterigmata $f$, young prothallium with a sterigma and gemma; $g$, growing end of filament. $\times 87$.

FIG. 17. A prothallium showing eleven growing points.

FIG. I8. A filament from a margin of a prothallium. $\times 45$.

\section{Plate 24}

FIGs. 19-22. Apex of prothallia showing sterigmata and gemmae. $\times 87$.

FIG. 23. Marginal cell, sterigmata and gemmae. $\times \mathbf{I} 20$.

FIGS. 24-26. Prothallia showing many-celled gemmae. $\times 25$.

FIG. 27. Gemmae. $\times 87$.

FIG. 28. Gemmae of six cells : cells $a, a$ forming rhizoids. $X \mathbf{I} 20$.

FIG. 29. Same as Fig. 28 , only older. $\times 87$.

FIG. 30. A gemma of which one cell has sent out a filament of three cells and an antheridium. $\times 87$.

FIGS. 3I, 32. Gemmae with rhizoids. $\times 35$.

FIG. 33. Gemma, with an antheridium, $a$, a rhizoid at each end and small aprothallium originating from two cells. $\times 45$.

FIG. 34. Gemma, with rhizoids and prothallium. $\times 35$.

FIG. 35. Gemma with a young prothallium originating from a single cell. $\times 87$.

FIG. 36. A gemma with two withered antheridia, $a$, $a$, and a young prothallium, from the margin of which have arisen three prothallia. $\times 35$.

FIG. 37. A gemma of five cells, bearing two rhizoids and two prothallia, the older one producing sterigmata and branching in two places. $\times 25$.

FIG. 38. Portion of the apex of the parent prothallium with two filaments : one still growing and bearing an antheridium, $a$, and a rhizoid, $b$, and the other filament (broken) and bearing two rhizoids. $\times 35$.

\section{Plate 25}

FIG. 39. Gemma showing an antheridium, $a$, as a small protuberance from one of the cells; the next cell has given rise to a filament of two cells, $b ; c, c$, rhizoids. $\times 87$.

FIG. 40. Gemma with an antheridium, $a$, showing first wall, $b ; c$, nuclei ; $d$, chlorophyl. $X \mathbf{I} 20$. In places the gemma is more than one cell wide.

FIGS. 4I-49. Stages in the development of the antheridia and antherozoids.

FIG. 4I. $a$, Nuclei. $\times 2$ Io.

FIG. 42. $a$, Peripheral cell ; $b$, cap cell ; $c$, central cell dividing into the mother cells of the antherozoids. $\times 2$ ro.

Figs. 43-45. Showing the different ways the walls may be formed, in tiers or obliquely ; $a$, central cell. $\times \mathbf{I} 20$. 
Figs. 46, 47. Looking down on the antheridium, showing the mother cells, $a$. $\times 2$ Iо.

FIG. 48. A ripe antheridium with the mother cells, $a$, lying free, each one containing an antherozoid. $\times 210$.

FIG. 49. An antheridium with two antherozoids still inside; $a$, ruptured cap cell ; the antheridium also showing the inflated peripheral cell, and inflated upper portion of the pedicel. $\times 210$.

FIG. 50. Three antherozoids, $a ; b$, cilia ; $c$, portion of mother cell. $\times 600$.

FIGS. 5I, 52. Two antheridia consisting of more than one peripheral cell. $\times 2$ IO.

FIG. 53. Gemma with three antheridia, one in the act of discharging the anther; ozoids ; $a$, rhizoid. $\times 88$.

Figs. 54, 55. Gemmae with antheridia, $a$, and rhizoids, $b . \quad X$ I 20.

FIG. 56. An antheridium from near margin of parent prothallium; $a$, antheridium ; b, pedicel. $\times 2$ Iо.

FIG. 57. Under side of wing of prothallium showing archegonia, $a, b$, the four stigmatic cells. $\times 87$.

FIG. 58. A prothallium with young sporophyte; $a$, prothallium ; $b$, archegonia ; $c$ first leat of young plant; $d$, root ; $e$, root hairs ; $f$, foot, $g$, scales around the growing tip of rhizome and next leaf. $\times 7$.

FIG. 59. Wing of a prothallium with three young archegonia, $a$, and sporophyte, b. $\times 5$.

Fig. 6o. $a$ of Fig. 59 magnified 35 times, to show young archegonia, $b ; c$, foot imbedded in the calyptra ; $d$, rhizome; $e$, root.

\section{Plate 26}

FIG. 6r. Longitudinal section of rhizome near apex, $a ; b$, young leaf; $c$, scales. $\times 12$.

FIG. 62. A portion of the same showing the differentiating tissues: $a$, apical portion; $b$, epidermis ; $c$, cortical parenchyma ; $d$, vascular bundle ; $e$, medullary parenchyma ; $f$, young scales. $\times \mathbf{1} 20$.

FIG. 63. Cross section of rhizome near tip, $a$, cortex; $b$, meristem of bundle; $c$, medullary parenchyma. $\times \mathbf{I} 20$.

FIG. 64. The same further from tip, $a$, cortex; $b$, medullary parenchyma; $c$, phloëm ; $d$, xylem, the walls of the tracheids thickening. $\quad X \mathbf{I} 20$.

FIG. 65. Older portion of rhizome. Marking as in Fig. 64. X 20.

FIG. 66. Cross section of the tubular bundle, $a$; showing two root bundles, $b$ and $c$; and the two bundles of a leaf, $d$, $d$; with a "foliar gap," $e ; f$, medullary parenchyma ; $g$, cortical parenchyma. $\times 45$.

FIGS. 67-71. Diagrams showing the different aspects of the tubular bundle in cross section, $a$, leaf bundles ; $b$, “foliar gap" of leaf above; $c$, root bundles. $\times \mathbf{I}$.

Figs. 72, 73. Outlines of scales. $\times 13$.

FIG. 74. The same, magnified ten times to show the cells. 


\section{VitTARIA LINEATA}

\section{Plate 27.}

Fig. 75. Basal portion of scale showing the thin-walled cells. $\times 87$.

FIG. 76. Cells from the margin half way up the scale showing the thin outer wall, $a$, and the papillae on the thickened inner walls, $b . \times 120$.

FIG. 77. Portion of scale showing the framework of suberized walls, $a . \times 120$

FIG. 78. The characteristic twist of the thin portion of the cross walls at margin. $\times 2$ ro.

FIG. 79. View of the back of the scale at base showing bend. $\times 25$.

FIG. 80. Base of scale showing twist. $\times 25$.

FIG. 81, 82. Apex of scales showing the wrinkling of the thin outer wall, $a$. $\times 871 / 2$.

FIG. 83. Longitudinal section through tip of root : $a$, root cap; $b$, apical portion ; $c$, parenchymatous cells ; $d$, meristem of axial bundle. $\times 45$.

FIG. 84. Tip of root showing how the cap cells often curl before being thrown off $-a ; b$, three cap cells still remaining attached to root.

FIG. 85. Portion of rhizome bundle showing connection of root bundle; $a$, endodermis ; $b$, phloëm ; $c$, xylem; $d$, cortex ; $c$, medullary parenchyma. $\times 120$.

FIG. 86. Diarch bundle of young root: $a$, cortex ; $b$, endodermis ; $c, c$, phloëm; $d, d$, two primary xylem groups. $\times 292$.

FIG. 87 . Cross section of young root : $a$, rhizoids ; $b$, cells containing crystalline substances ; $c$, endodermis ; $d$, the two phloëm groups ; $e$, xylem. $\times 38$.

FIG. 88. Cross section through root and two of its branches, and a longitudinal section through a third branch at its point of attachment with the first root: 2 was given off first; then 3 ; and then 4 . Marking as in Fig. $87 . \times 45$.

\section{Plate 28}

FIGs. 89, 90. Prothallia and young sporophytes growing on the bark of the palmetto. $\times 3$.

FIG. 91. A wing $a$, of the prothallium showing young sporophyte; $b$, first leaf; $c$, root. $\times 9$.

FIGS. 92, 93. Rudimentary primary leaves showing variation. $\times 2$.

FIG. 94. Variation of secondary leaf.

FIG. 95. Mature sterile leaf, the sporophyll shows the same variation with the exception that the two primary veins, $b$, are apt to run a longer distance before anastomosing; 2 is basal portion of $\mathrm{I}$, they join at $a ; b$ primary veins. $\times 2$.

FIG. 96. Apex of first leaf showing epidermis of under side of hyaline border. $\times 871 / 2$.

FIG. 97. Portion of epidermis of same under side : $a$, gland; $b$, stoma. $\times 2$ Io.

FIG. 98. Portion of epidermis showing prosenchymatic cell $a . \quad \times 2$ Io.

FIG: 99. Scale from upper side of first leaf. $\times 87$.

FIG. Ioo. Cross section of petiole showing vascular bundle with two xylem groups, $b$, in primary leaves. $\times 25$. 


\section{Plate 29}

FIG. IOI. Surface view of rhizome, with the leaves removed to show the tworanked arrangement, and the two primary bundles. $X \mathbf{I} \mathbf{I}$.

FIG. 102. Diagram of leaf bundles : $a$, bundle of rhizome; $b$, the two primary bundles ; $c$, first lateral bundle ; $d$, second lateral bundle.

FIG. I03. Nine diagrams showing different cross sections of leaves with bundles. In $2,3,4$ and 5 the thick-walled cells surrounding primary bundles have united before the formation of the lateral bundles, and shows the primary bundles anastomosing after the lateral bundles have been given off; 9 shows the apex of a leaf with one lateral bundle ending free.

FIG. I04. Diagram of middle portion of leaf : $a$, central bundle composed of parts of the two primary bundles; $b$, thick-walled cells surrounding bundle; $c$, mesophyll ; $d$, band of thick-walled cells and epidermis ; $e$, groove (under side of leaf) ; $f$, lateral bundle; $g$, denser mesophyll of upper side of leaf. $\times \mathbf{1} 3$.

FIGS. 105, 106. Cross sections of petioles showing different degrees of thickening of the outer parenchymatous cells of the cortex. Fig. I05 is more often found in the sporophylls. I, upper side; $a$, primary bundles. In Fig. 106 one lateral bundle is shown, $b . \times 25$.

FIG. 107. Cross section of central bundle of leaf; $a$, phloëm ; $b$, xylem; $c$, endodermis ; $d$, thick-walled cells of the ground tissue surrounding bundle. $X \mathbf{1} 20$.

FIG. 108. Cross section of one of the lateral bundles. Marking as in Fig. 107. $e$, mesophyll of under side; $f$, thin-walled epidermal layer which gives rise to the sporangia. $\times \mathbf{1 2 0}$.

FIG. I09. Curled apex of young sporophyll showing scales, $a$, and cut so as to show the bundles, $b$; and grooves, $c . \times 15$.

FIG. I IO. Side view of apex of young leaf showing curl and glands. $X \mathbf{I} 3$.

FIG. III. Front view of same. $\times I_{3}$.

FIG. I 12. Portion of epidermis from under side of young leaf ; $a$, scale ; $b$, gland ; $c$, stoma just forming. $\times 87$.

\section{Plate 30}

FIG. I 13. Apex of leaf. Dotted line indicates the area of the dense mesophyll cells, containing chlorophyll, under epidermis. $\times 87$.

FIg. I I4. Portion of upper side of leaf, over bundle, seen in cross section; $a$, epidermis; $b$, thick-walled cells, generally prosenchymatic, often becoming bast-like; $c$, mesophyll cells containing chlorophyl. $\times 87$.

FIG. II5. Portion of epidermis, $a$, from under side of young frond showing first stoma, $d$. Marking as in Fig. I 14.

FIG. I 16. Ridge over bundle on under side. $\times 87$.

FIG. I17. Inner margin of groove extending from ridge to ridge: Marking as in Fig. I 14. $\times 87$.

Figs. 118, I19. Illustrate peculiar folding of the epidermal walls. Fig. I19 has been treated with potash to show the way they fit into each other.

FIG. I 20. Diagram of surface of under side of leaf showing the ridge and lateral grooves, $a$, the stomata and glands. $\times 13$.

FIG. I 21. Epidermis from groove; $a$, stoma ; $b$, gland. $\times 87$. 
Fig. I22. $A$, represents width of groove from edge to the sporangial layer; $b$, stoma ; $c$, initial cell ; $d$, original epidermal cell.

FIG. I 23. Cross section of groove : $a$, stoma ; $b$, epidermal cell ; $c$, air space ; $d$, thick-walled cells around bundle; $e$, thin-walled epidermal layer giving rise to the sporangia, $f$, and paraphyses, $g . \quad \times \mathbf{I} 20$.

Figs. I 24-126. Showing origin of the stoma : $a$, original epidermal cell ; $b$, initial cell of the stoma ; $c$, the mother cell of the stoma ; $d$, longitudinal wall through mother cell, in Fig. 126, dividing it into the two guard cells, $e, e ; f$, nucleus; $g$, chlorophyl. $\times 294$.

Fig. I 27. Mature stoma. Dotted line, $h$, represents wall of mother cell, the two guard cells being raised somewhat above the epidermis as in the cross section (Fig. 123). Marking as in Figs. 124-126. $\times 310$.

FIG. 128. Gland. $\times 294$.

\section{Plate 3I}

FIG. I29. A diagram of the longitudinal section of the leaf passing through center of groove : $a$, upper epidermis and band of thick-walled cells ; b, mesophyll ; $c, c$, band of thick-walled cells surrounding bundle; $d$, lateral bundle; $e$, thin-walled layer of epidermis giving rise to the sporangia ; $f$, sporangia here shown in all stages of development ; $g$, the paraphyses. $\times 25$.

FIG. I30. Nine sections showing the development of the sporangium : $a$, original cell of the sporangium; $b$, first oblique wall ; $c$, second wall ; $d$, first tetrahedral cell ; $e$, peripheral cell dividing to form the sporangial wall. No. 9 shows the divisions of the tetrahedral cell, which form the mother cells of the spores and the tapetal cells, $g ; h$, pedicels. No. 5, surface view of very young sporangium. $X \mathbf{I} 20$.

FIG. I3I. Nos. I and 2. Surface views of older sporangia : $a$, annulus; $b$, lip cells just forming ; $c$, cells of pedicel at base of sporangium. $\times$ I 20.

FIG. I32. Mother cells from a young sporangium before dividing to form the spores. $\times 210$

FIG. I33. Young sporangium, all the cells containing chlorophyl, except the lip cells; $a$, annulus ; $b, b$, four connective cells ; $c$, the four lip cells ; $d$, thin-walled cells of sporangial wall; $e$, pedicel. $X \mathbf{I} 20$.

FIG. I34. Ripe sporangium showing the way in which it opens : $f$, spores. Marking as in Fig. $133 . \quad \times 120$.

FIG. 135. Different ways in which cells of pedicel divide; part of the basal portion of the sporangium is shown at $a$ in No. I. No. $\mathbf{I}, \times 87$. No. $2, \times \mathbf{I} 20$.

FIG. I36. Four cells from epidermal layer, $a$, one of which has given rise to a young sporangium, $b ; c$, first tetrahedral cell in process of dividing (this stage is between Nos. 8 and 9 of Fig. I30) ; $d$, sporangial wall ; $e$, pedicel ; $f$, young paraphysis from adjoining cell containing a nucleus and some chlorophyl. $X \mathbf{I} 20$.

Figs. 137, 138. Young paraphyses. $X \mathbf{1} 20$.

FIG. I39. Seven diagrams showing the branching of the paraphyses.

FIG. I40. Young sporophyte, $b$, growing from mutilated end of rhizome, the growing apex of rhizome having been removed; $a$, base of two old sporophytes. 



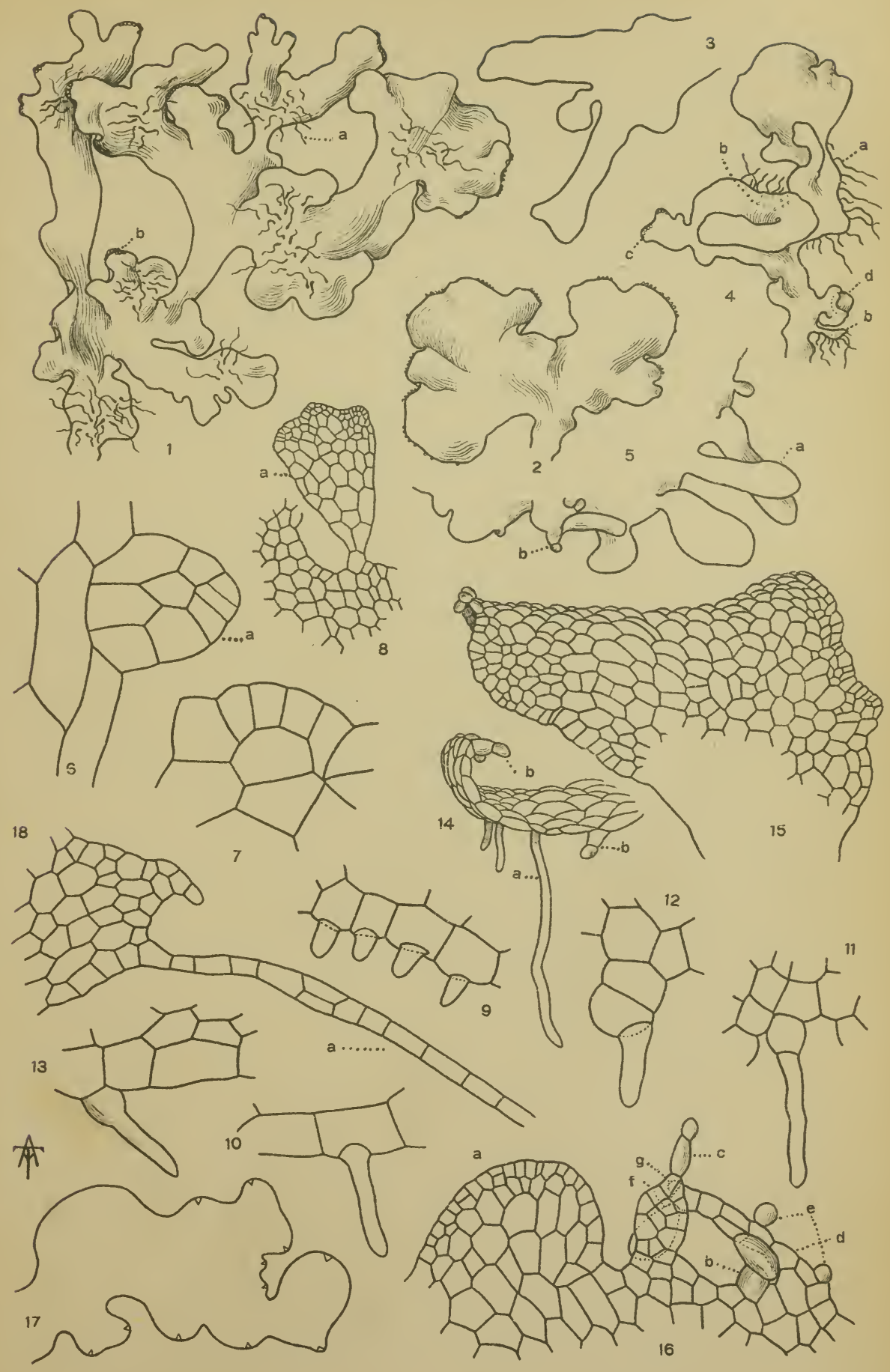

VITTARIA LINEATA 



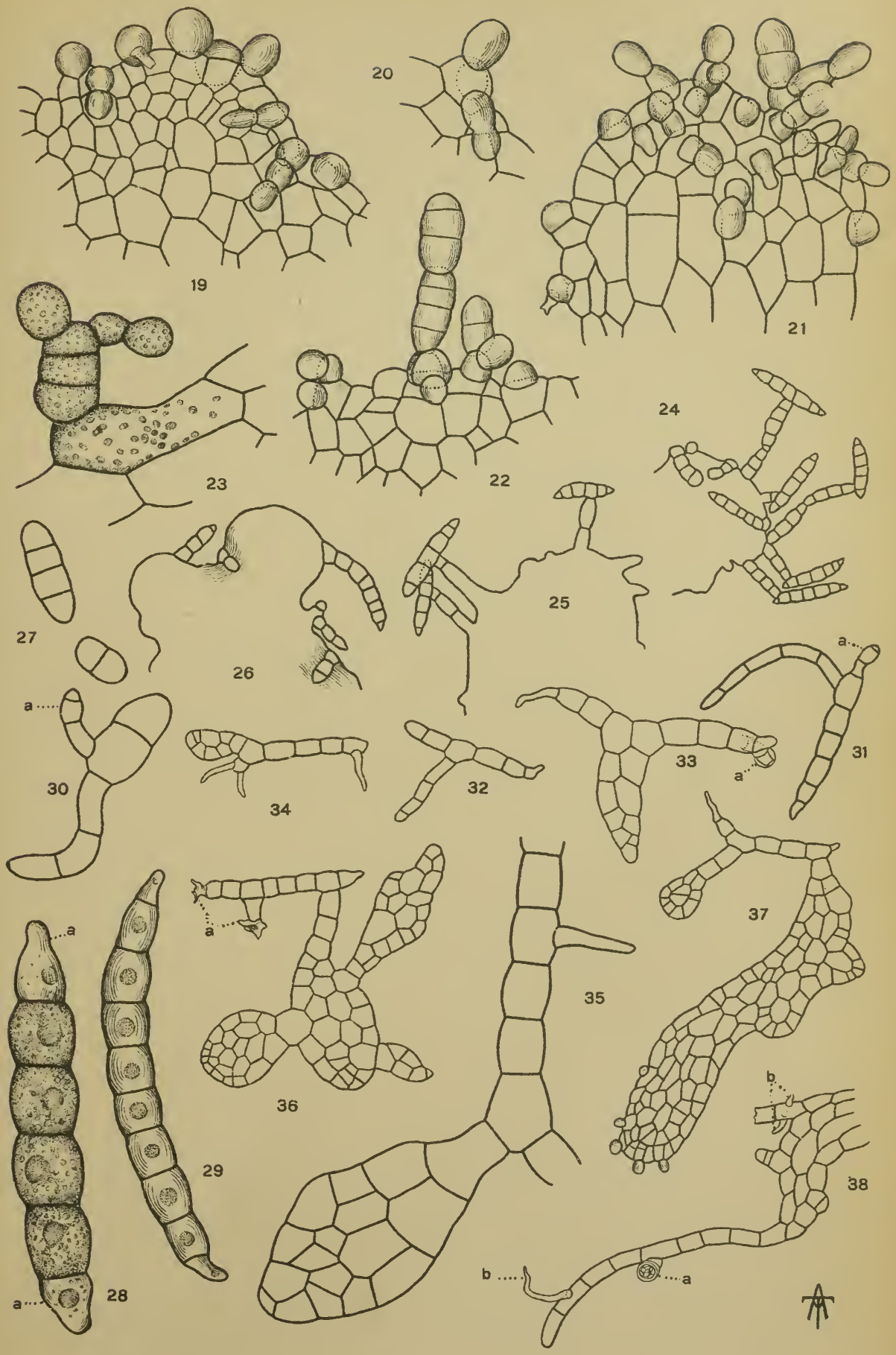

VITTARIA LINEATA 



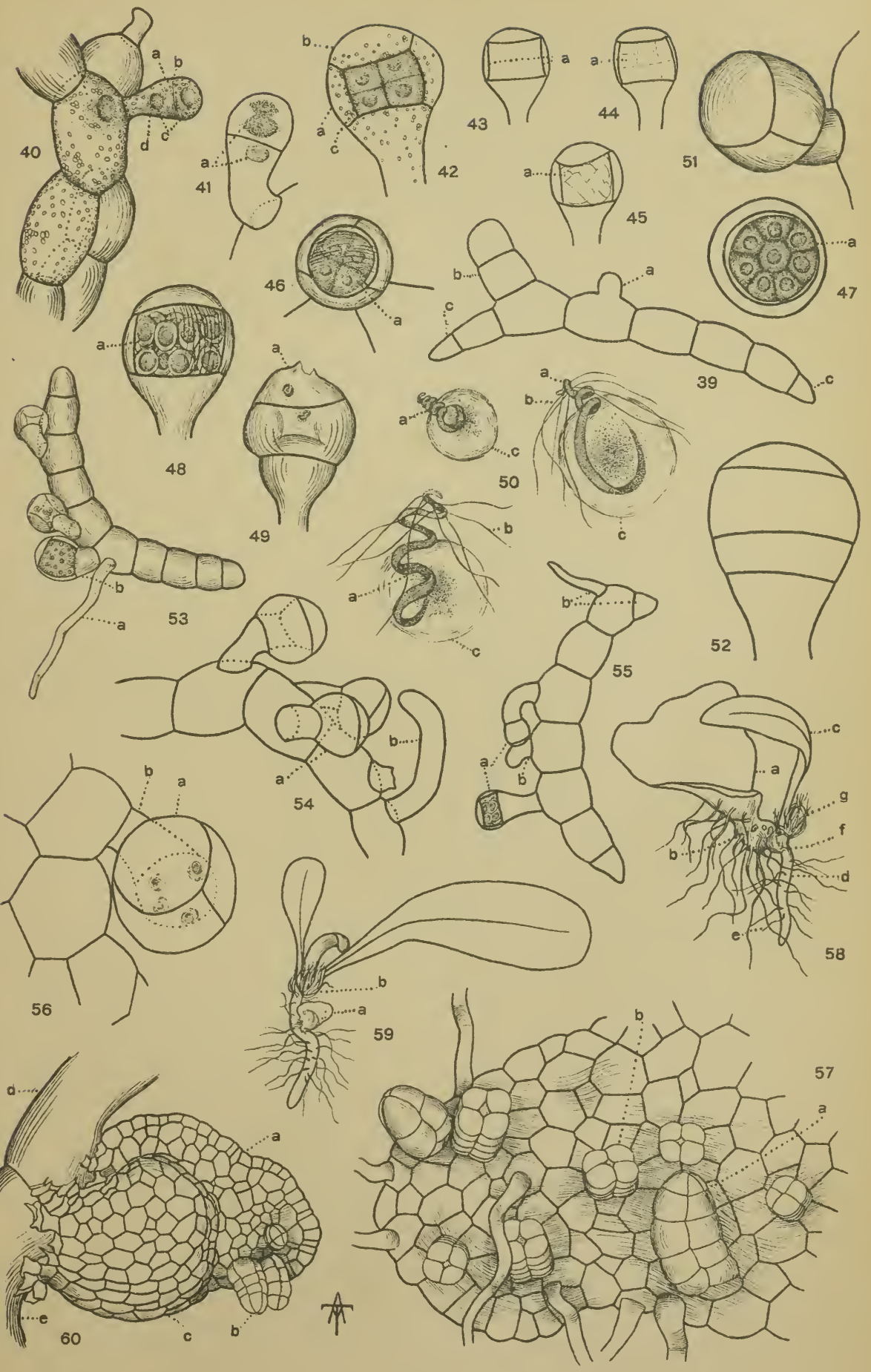

VITTARIA LINEATA 



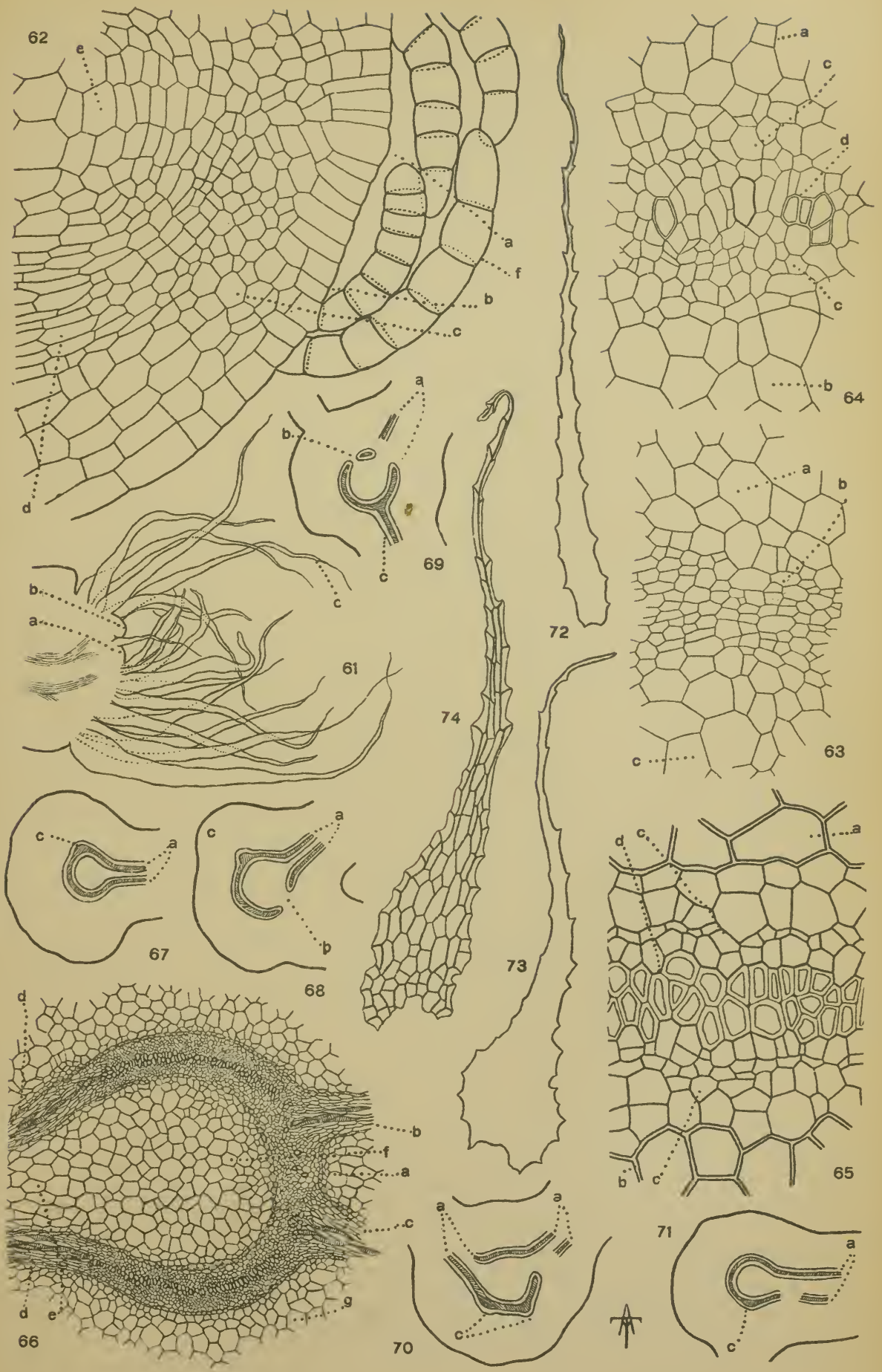

VITTARIA LINEATA 



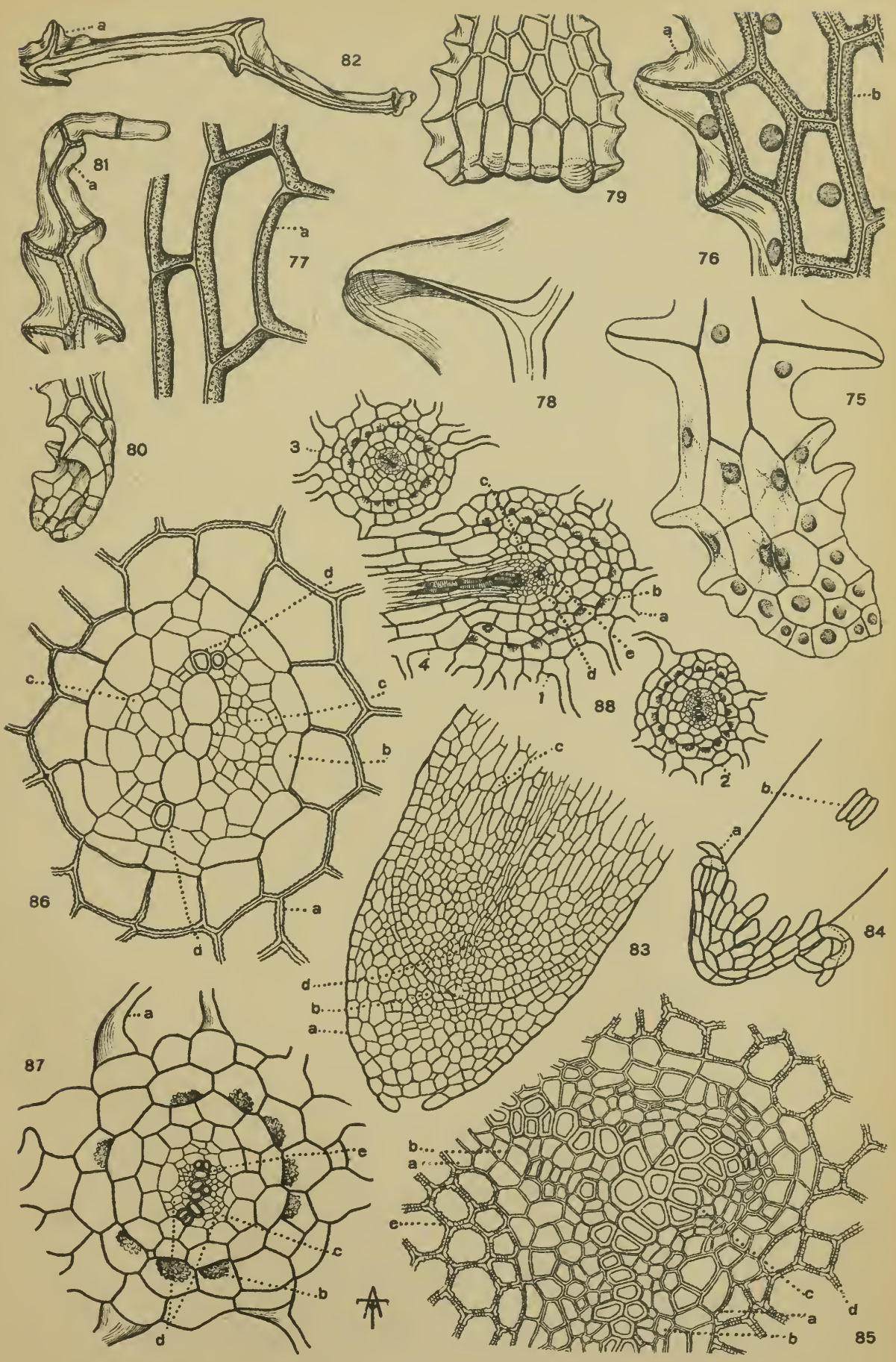





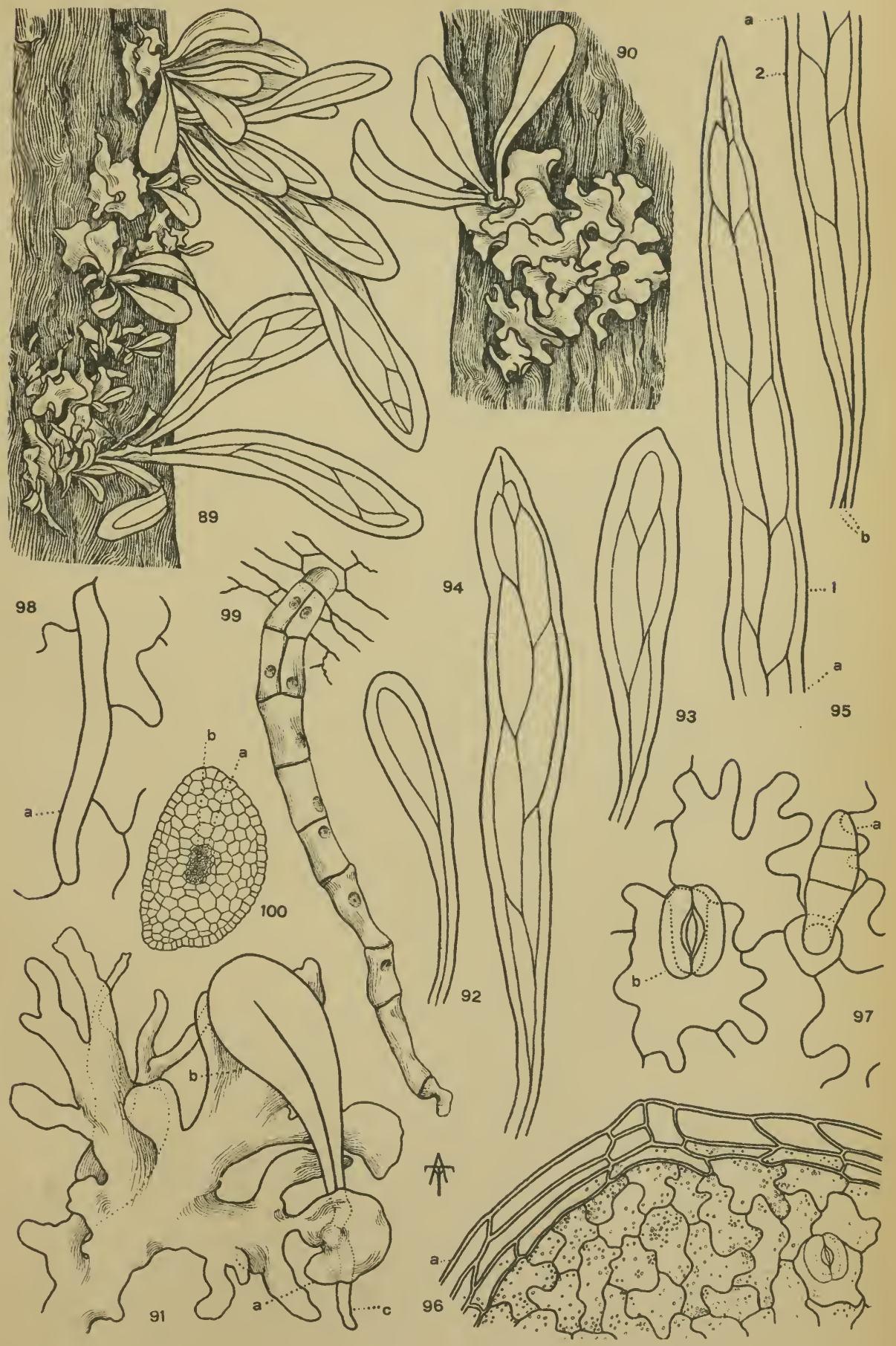





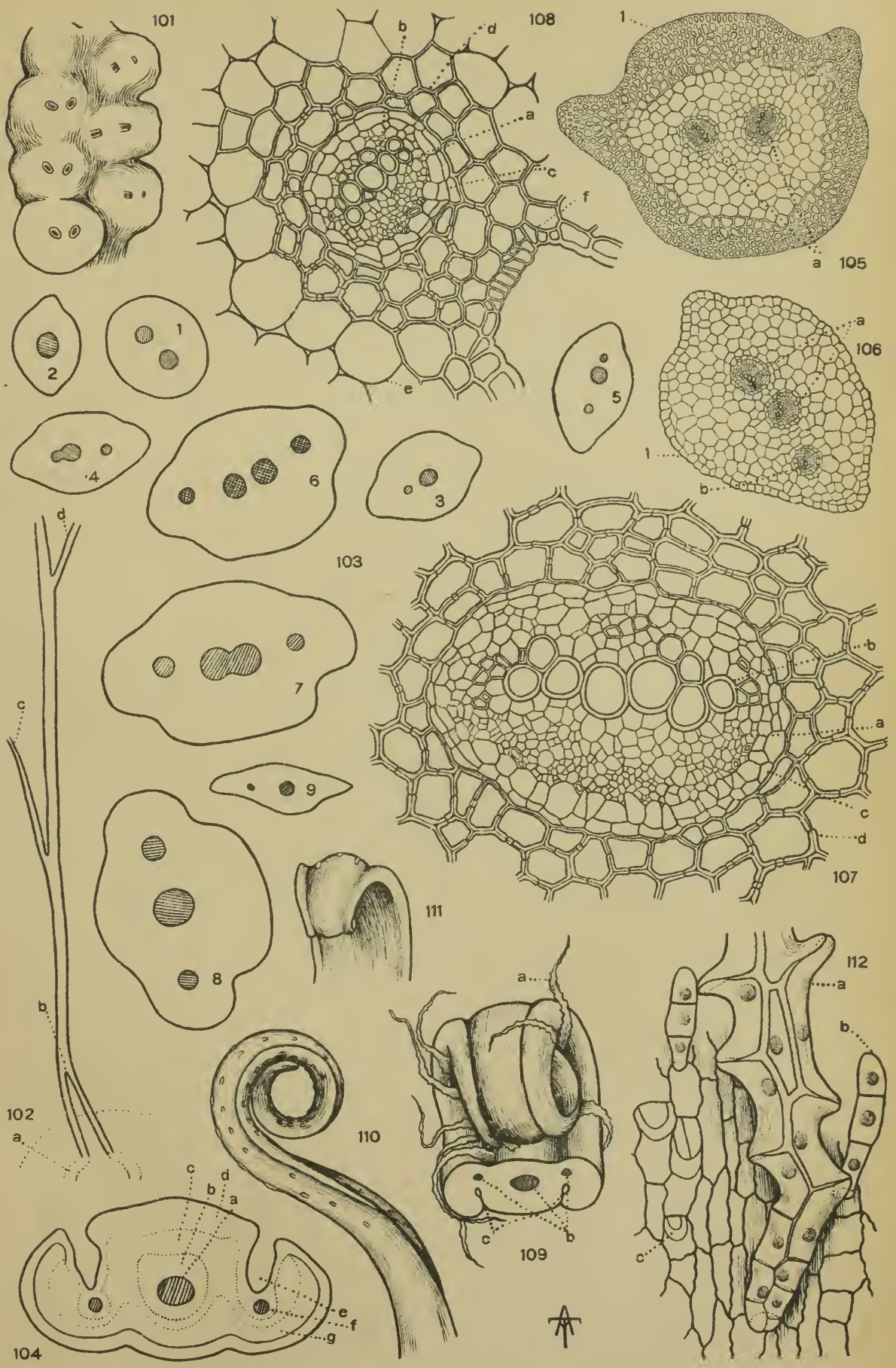

VITTARIA LINEATA 


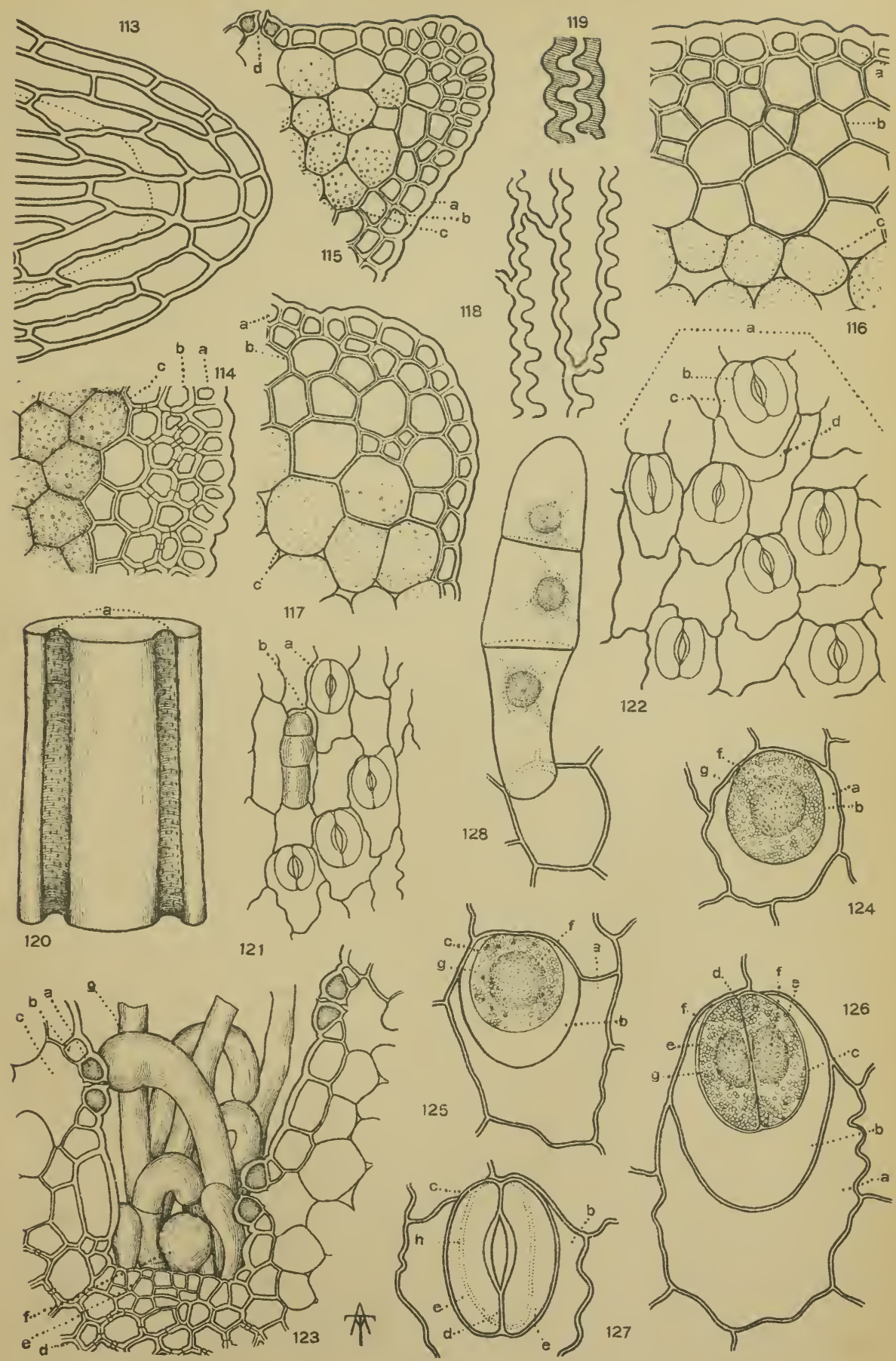



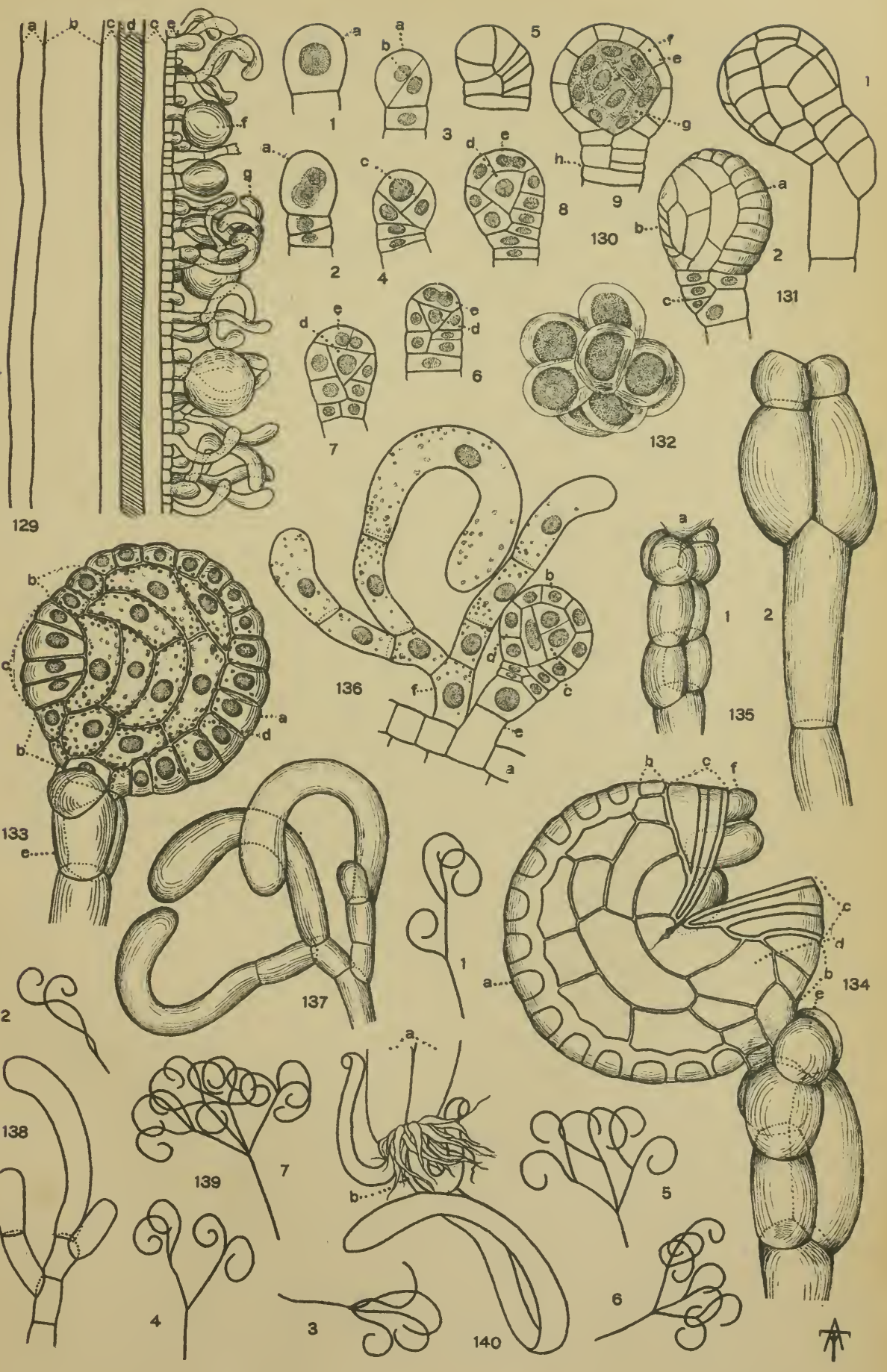

VITTARIA LINEATA 





WELLESLEY COLLEGE LIBRARY

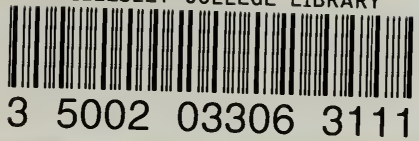

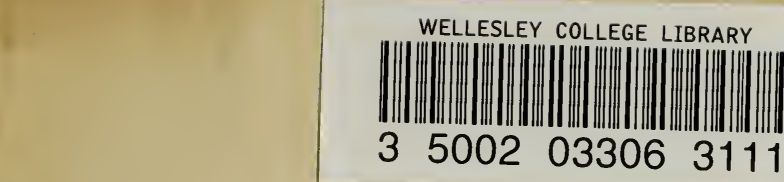

.

(⿸丆口
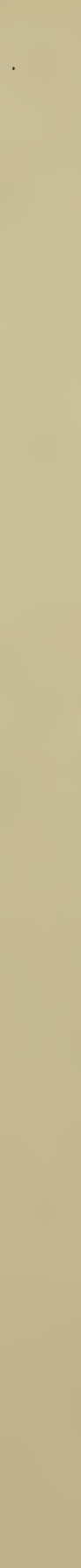


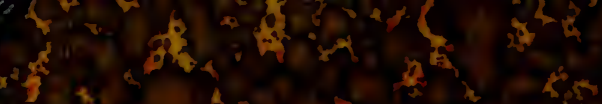

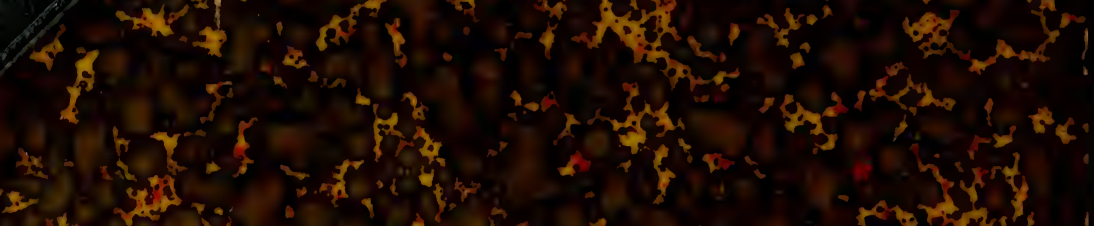

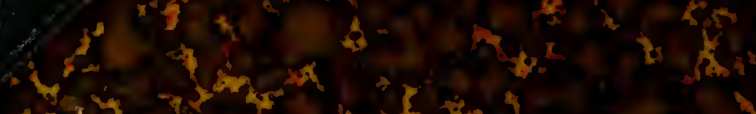

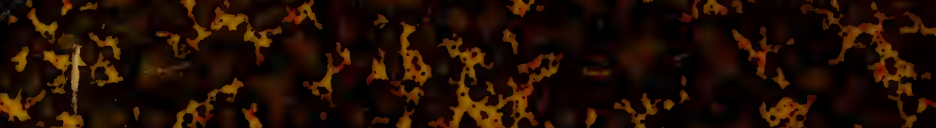

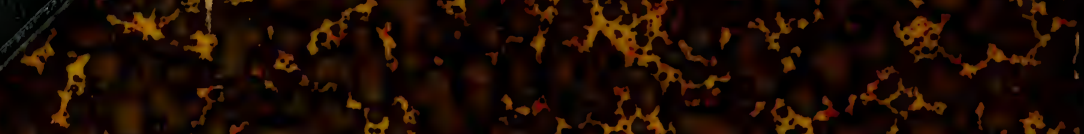

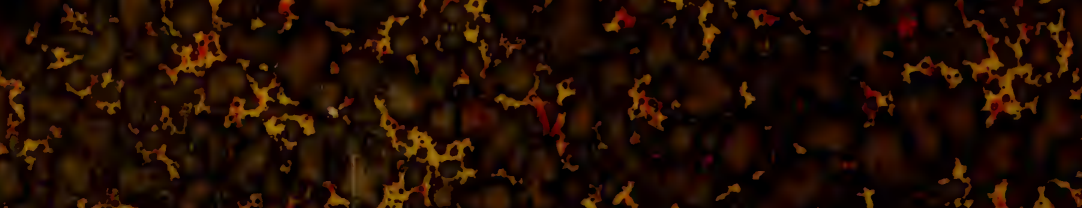

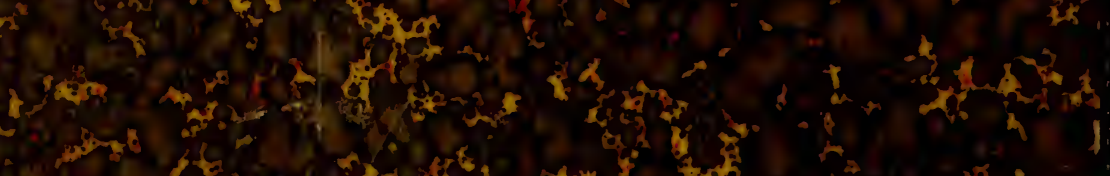
(1)

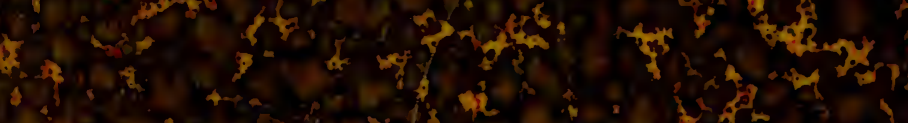

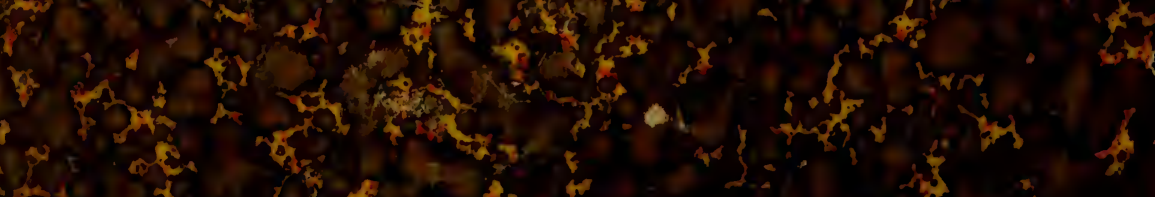

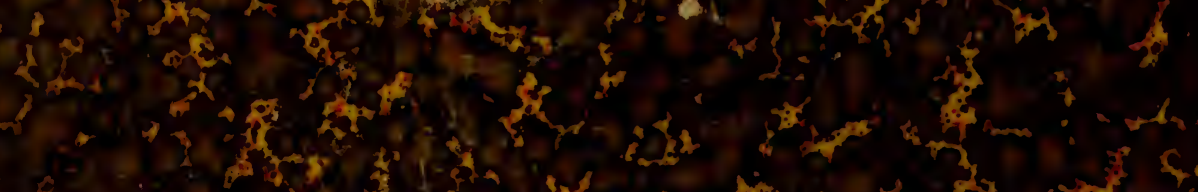

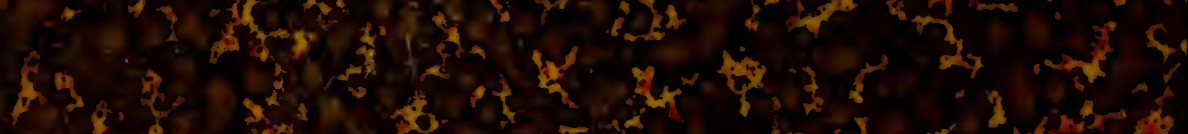
4

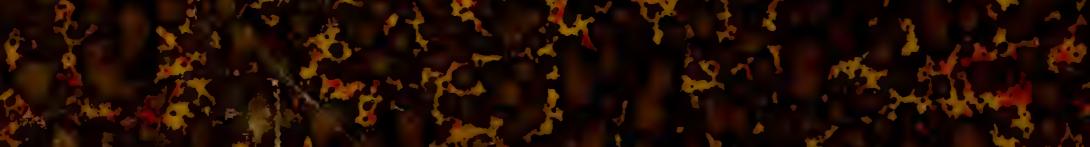

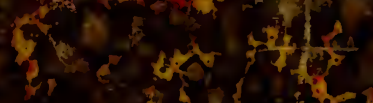

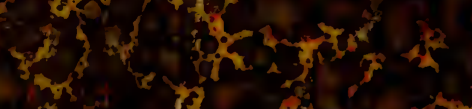

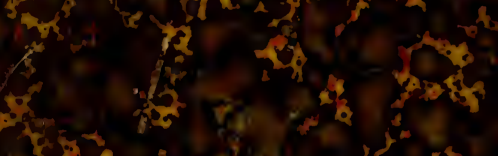

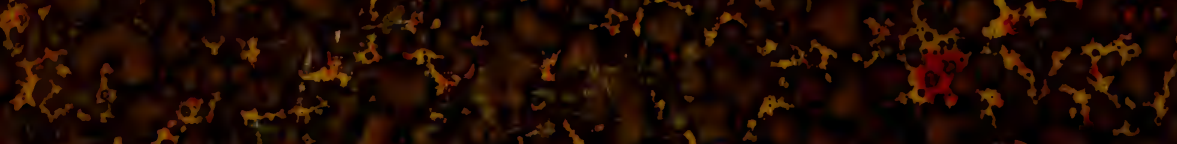

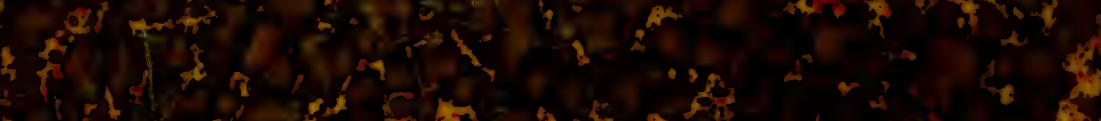

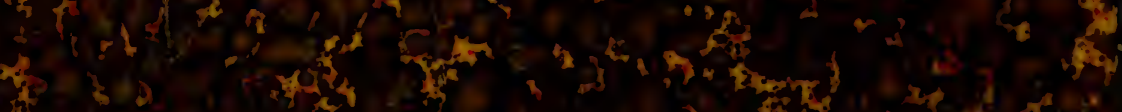

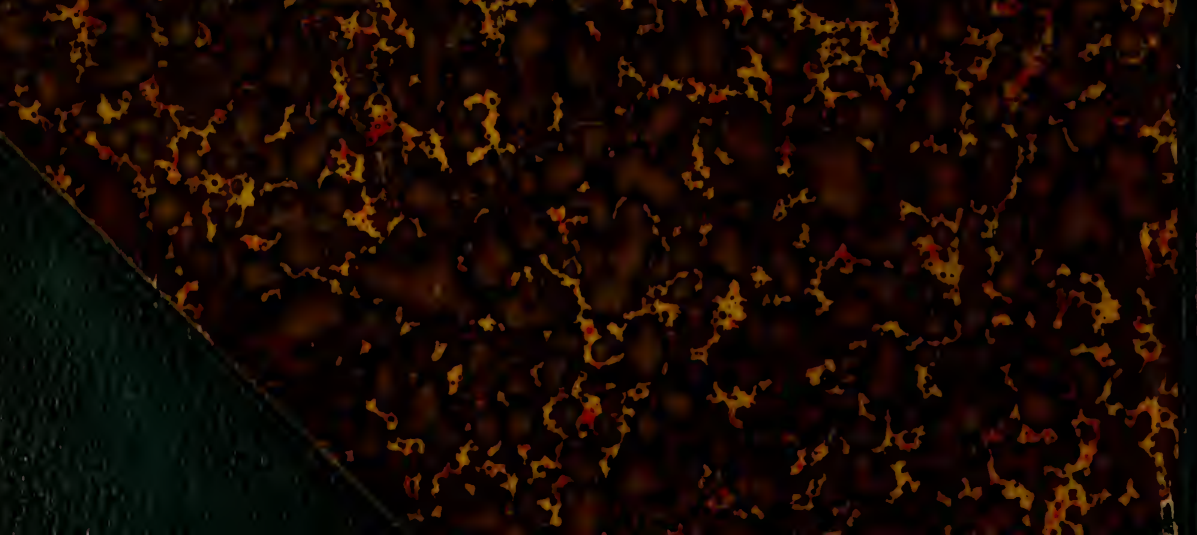

